\title{
Venice According to Odyniec (and Mickiewicz?) in Romantic Contexts
}

\section{S U M M A RY}

This text is a reconstruction of the image of Venice offered in Listy z podróży by Antoni Edward Odyniec. Against the background of Romantic traditions (Byron, Chateaubriand, Shelley, and Radcliffe), I present how the author shaped the portrait of Venice suspended between the Romantic vision of the city/monster (Leviathan) and the ballad-based vision of the city/Siren. I indicate not only the fact that the image of Venice was rooted in the sentimental/Romantic stereotype, but I also define to what extent it was formed by the imagined world of Polish nobility, i.e. szlachta. Most of all, however, I am interested in the traces present in Listy z podróży which enable one to uncover Mickiewicz's influence on how Odyniec shaped the image of Venice.

\section{Keywords}

Adam Mickiewicz, Antoni Edward Odyniec, Venice, Romanticism, journey.

Mickiewicz arrived with Odyniec in Venice on 7 October 1829 "at one in the afternoon"; they stayed at the de Luna Inn, from where they moved the very next day to a private apartment at "Ponte dei Dai, Torre Correnta, al. Moro." Their visit lasted until 20 October and it was recorded by Antoni Edward Odyniec in a fragment of Listy z podróży that he wrote to Julian Korsak and Ignacy Chodźko. His description raises a major question: to what degree 
can one reconstruct Mickiewicz's influence on the image of Venice depicted by the author of Listy?

The answer is difficult not only due to a vague depiction of the poet's relationship with the city, but also the vague status of the fragment (similarly to other fragments in the two-volume story) regarding Mickiewicz and Odyniec's visit in Venice. Being aware of the author's tendency to exaggerate and fabricate facts, literary historians doubt his credibility. Nor are they certain when it was written: during his journey or maybe much later, e.g. in the 1860s, when the author started publishing it in the Kronika Rodzinna journal (1867-1878). The nature of the text prevents researchers from establishing any borderline, even a hypothetical, between an account rooted in his autobiography and fiction inspired by his readings. Thus, it also raises questions about to what extent the image of the city created by Odyniec was a projection of his personal experience and to what extent it was determined by the pressure of the models already established in culture - in iconography, literature, and in language itself, i.e. in stereotypes which had arisen around the location, in perceptive clichés, and in customary formulations of collection visions. ${ }^{1} \mathrm{I}$ am interested in that entire mediatory sphere which influenced the presentation of the image of Venice in its Polish 19th-century variant.

The author of Listy followed the models of traditional travel writing as practised by, e.g. Klementyna Hoffmanowa née Tańska or Łucja Rautenstauchowa née Giedrojć. Their narratives were supposed to be a source of information about the cultures and the social spaces of specific times and places. Their function was highly educational, and they were intended for specific readers who defined the cultural and moral horizons of the texts. Odyniec followed that route. He clearly indicated the aim of his account: "I shall offer you a small guided tour around Venice." His narration referenced his experience of 1829, i.e. a time when the vision of Venice was shaped in literature by texts by Johann Wolfgang von Goethe, ${ }^{2}$ Ann Radcliffe, ${ }^{3}$ Germaine de Staël, ${ }^{4}$ and most significantly Lord Byron. ${ }^{5}$ It seems, however, that - as he was preparing it for print many years after his journey - Odyniec also used other later accounts. It bears some resemblance to the narratives by Chateaubriand $^{6}$ or Łucja Rautenstrauchowa. ${ }^{7}$

${ }^{1}$ Elżbieta Rybicka, "Problematyka urbanistyczna w literaturze polskiej XVIII i XIX wieku (Wybrane zagadnienia)," in Modernizowanie miasta. Zarys problematyki urbanistycznej w nowoczesnej literaturze polskiej (Krakow: Universitas, 2003), 33-70.

2 Johan Wolfgang von Goethe, Aus meinem Leben. Dichtung und Wahrheit. Zweiter Abteilung Erster Teil, (Jena: Frommann, 1816-1817), vol. 1, 2. See Goethe, "Italienische Reise," in Goethes Werke. Volständige Ausgabe letzter Hand (Stuttgart and Tübingen: Johan Georg Cotta, 1829) vol. 27, 28.

${ }^{3}$ Ann Radcliffe, The Mysteries of Udolpho, (London: G.G. and J. Robinson, 1794).

${ }^{4}$ Germaine de Staël, Corinne, ou l'Italie, (Paris: Henri Nicolle, 1807). 1818).

${ }^{5}$ Lord George Gordon Byron, Childe Harold's Pilgrimage, Canto IV, (London: John Murray,

${ }^{6}$ François Renè de Chateaubriand, "Memories d'Outre - Tombe," La Presse (1848-1850).

${ }^{7}$ Lucja Rautenstrauchowa, Miasta, góry i doliny. (Poznań: Nowa Księgarnia, 1844), vol. 3; W Alpach i za Alpami (Warsaw: Merzbach, 1850), vol. 3. 
The plan of the guided tour in Listy z podróży was dictated by Byron's relationship with Venice. That path was, in fact, followed by many travellers, particularly in the first half of the 19th century (Chateaubriand, Krasiński). One could state that the task of finding the traces of "the greats of the epoch" in the city became one of the main attractions at that time. However, to follow it one had to possess extensive knowledge ${ }^{8}$ and not all travellers, like Chateaubriand, were invited to aristocratic manors, where people discussed the poet's lifestyle in Venice. ${ }^{9}$ Nonetheless, the main source of information about Byron's relationship with the city were his memoirs and letters, and his literary works with which Polish travellers were familiar. Already in the statement opening his travel story, Odyniec referred to the initial lines of Canto IV of Childe Harold's Pilgrimage: "I stood in Venice, on the Bridge of Sighs; / A palace and a prison on each hand."10 It is noteworthy that the author of The Giaour indicated Venetian locations not only in Childe Harold's Pilgrimage, but also in his historical tragedies Marino Faliero, Doge of Venice and The Two Foscari, in the narrative poem "Beppo," and in "Ode on Venice." Their common presence was both an outcome of Byron's conviction that words can save a place, and of his Romantic interest in history, a quality which both Mickiewicz and Odyniec also shared. Of course, the Venetian traces left by the author of Don Juan led travellers not only to the Doge's Palace, the Bridge of Sighs, or to the prison, i.e. locations extremely popular among 19th-century visitors. They also followed him to the island of Lido where he rode a horse and imagined he would be also buried there. ${ }^{11}$ They journeyed to Malamocco, which John Hobhouse, Byron's friend, referenced in "Historical Notes" to Childe Harold's Pilgrimage. ${ }^{12}$ It was also included in

\footnotetext{
${ }^{8}$ That was indicated by François Renè de Chateaubriand: "I was shown a place where he would swim: a plaque with his name was put in the centre of the Grand Canal (...) The lord's emblem disappeared from the place where it was displayed. Austria extended a veil of silence over everything." "Księga o Wenecji," trans. Paweł Hertz, Zeszyty Literackie, issue 3 (1992): 84.

${ }^{9}$ Chateaubriand referenced stories about Byron which he learnt from ladies Albrizzi and Benzoni, who used to invite the lord to their Venetian houses. Ibid., 80-84.

${ }^{10}$ Lord George Gordon Byron, "Wędrówki Czajdl Harolda," trans. Jan Kasprowicz, in Wybór dziet, selected, foreword, ed. and notes by Juliusz Żuławski, trans. Jan Kasprowicz (Warsaw: PIW, 1986), vol. 1, 568. [English version: Lord George Gordon Byron, Childe Harold's Pilgrimage (98). Kindle Edition]

11 "I hope, whoever may survive me, and shall see me put in the foreigners' burying-ground at the Lido, within the fortress by the Adriatic, (...) I trust they won't think of 'pickling, and bringing me home to Clod or Blunderbuss Hall.' I am sure my bones would not rest in an English grave, or my clay mix with the earth of that country. I believe the thought would drive me mad on my deathbed, could I suppose that any of my friends would be base enough to convey my carcass back to your soil. I would not even feed your worms, if I could help it. Byron "List do Johna Murraya, Bolonia 7 czerwca 1819," in Listy i pamiętniki, ed. Juliusz Żuławski, trans. Zygmunt Kubiak, Stanisław Kryński, Bronisław Zieliński et al. (Warsaw: PIW, 1960), 216. [English version: Life of George Byron, accessed 27.10.2020, http://www.gutenberg. org/files/16549/16549-h/16549-h.htm] Antoni Edward Odyniec revealed that he knew about Byron's desire (Listy z podróży, ed. Marian Toporowski, introduction by Maria Dernałowicz vol. 1 (Warsaw: PIW, 1961), 419).

${ }^{12}$ Byron, "List do Johna Murraya, Rzym 15 września 1817," in Listy i pamiętniki, 186. The poet revealed that Hobhourse had written footnotes to Canto the Fourth of Childe Harold's Pilgrimage. See John Cam Hobhouse, Historical Illustrations of the Fourth Canto of Childe Charold: Containing Desertations on the Ruins of Roma and am Essay on Italian Literature. (London: John Murray, 1818).
} 
the poet's Venetian space, similarly to Saint Lazarus Island inhabited at that time by Armenian monks who had arrived from Greece already in the early-18th century and who persistently practised their craft of editing. Byron mentioned the fact of learning Armenian, which was probably the reason why Mickiewicz and Odyniec also decided to follow in his footsteps. ${ }^{13}$

Significantly, Polish travellers associated Byronic traces with Napoleon. They travelled to Murazzi, a fortress erected in 1744-1782, which was supposed to protect Venice against the sea. That was a trail which was indicated by Goethe. One could say that it was made more attractive by Napoleon, as it was he who ordered the construction of another dam. References to the grand leader were made in travel narratives mostly in relation to the role he had played in the history of Venice, a fact which Odyniec, unlike e.g. Chateaubriand, omitted. Usually, they referenced inglorious deeds. They indicated acts of destroying and looting works of art conducted at Napoleon's consent. Odyniec most probably avoided references to Napoleonic times in his travel narrative because of censorship that was introduced by the partitioning states, yet his silence in this respect could had also been a result of his unwillingness to be critical of Napoleon. The author of Listy left the topic of Napoleon to Mickiewicz, and, in following Lord Byron, he referenced the quadriga from St. Mark's Basilica, the horses which were removed by Napoleon's order, although they were returned to Venice already in 1815. That story was already part of a fairly consolidated canon at that time. It is noteworthy that later it received a bitter Polish extension in Popioty by Stefan Żeromski.

Odyniec and Mickiewicz's journey followed the obvious route in the 19th century: to St. Mark's Basilica, and to St. Mark's Square, Piazzetta, St. Mark's bell tower, to the Arsenal, Venetian theatres and galleries with the referenced Academy of Fine Arts, and, finally, to churches of which they supposedly visited fifty, though the author of Listy only mentioned two by name. Odyniec also went without the poet on a popular trip at that time to Murano, while together they travelled in a gondola "a quarter of a mile off the city" and along the Grand Canal.

\section{"Names" and images of Venice}

For Polish travellers, Lord Byron did not only define various trails around the city and its lagoon surroundings. In Childe Harold's Pilgrimage, he referenced the model visions of Venice created by such painters as Paolo Veronese, Giacomo Palma il Giovane, and Giovanni Battista Tiepolo, presented at the Doge's Palace. ${ }^{14}$ They were the authors of the image of Venice as a woman ruler. They modelled it on Daniele Barbaro's ideological plan, the main

${ }^{13}$ By reading the letters and journals by the author of Korsarz, other travellers had yet another opportunity. For example, to consider the Grand Canal, the city's thoroughfare, as a trail once travelled by Byron, they could also search for the place where he slipped and fell into a canal, or see the famous Rialto Bridge recollecting its window-framed view recorded by him.

${ }^{14}$ Giovanna, Sciré Nepi, Augusto Gentili, Giandomenico Romanelli, Philips Rylands, Wenecja. Arcydzieła malarstwa, trans. Tamara Łozińska (Warsaw: Arkady, 2014). 
objective of which was to praise the trade and military strength of the city on the lagoon - its majesty and grandness. That is why artists mostly focused on Venice's positive features. They praised its justice, ${ }^{15}$ it was presented as a warrant of prosperity; ${ }^{16}$ as a guardian of happiness, honour, freedom, fame, safety, ${ }^{17}$ as a victor, ${ }^{18}$ as being showered with riches by pagan gods ${ }^{19}$. Over several centuries, painters shaped its image as a powerful woman, sitting on a throne with a lion resting at her feet. She appeared in the role of a monarchess bearing royal attributes: a crown, a sceptre, and an ermine coat. That was the official image which was promoted in the Republic. In literature, the portrait was much more modest, though its main qualities, i.e. majesty and dominance, were retained. Goethe referred to Venice as "ruleress married to the sea," 20 and he added a mythological thread writing about an entity/city which formed on a lagoon "which leaped out of the sea like Pallas from Jupiter's head."21

In Childe Harold's Pilgrimage, Byron clearly referred to the iconography established in painting. In the narrative poem, it was a ruleress dripping with riches: "In purple she was robed, and of her feast/ Monarchs partook," "and the exhaustless East/ Poured in her lap all gems in sparkling showers." 22 It is possible he associated it with Cybele ${ }^{23}$ as in that character he saw similarities to the portraits presented in the Doge's Palace. That Anatolian mother goddess was also presented as a ruleress. She was placed on a throne with a lion by her side, "Rising with her tiara of proud towers," 24 as the poet wrote in Childe Harold's Pilgrimage. Thus, through literature, Byron consolidated the visions of Venice created by painters. But also, by making her "a ruler of the waters and their powers, ${ }^{\prime 25}$ he modified her image. He referred to

${ }^{15}$ Paolo Veronese, Venice on a throne honored by Justice and Peace, 1575-1578, ibid., 329.

${ }^{16}$ Paolo Veronese, Venice receives the homage of Hercules and Ceres, 1575-1578, ibid., 330.

${ }^{17}$ Paolo Veronese, Triumph of Venice, 1579-1582, ibid., 355.

18 Jacopo Palma il Giovane, Venice Crowned by Victory, 1578-1579 and Nicolò Bambini, Triumph of Venice, 1682, ibid., 354, 394.

${ }_{19}$ Paolo Veronese, Juno Showering Gifts on Venetia, 1554-1555; Giovanni Battista Tiepolo, Neptune Offering Gifts to Venice, 1750-1760, ibid., 316, 440-441.

${ }^{20}$ Johann Wolfgang Goethe, Podróż włoska, trans., notes and afterword by Henryk Krzeczkowski (Warsaw: PIW, 1980), 56.

${ }^{21}$ Ibid., 118.

${ }^{22}$ Byron, Wędrówki Czajdl Harolda, Canto IV, 568, lines 15-18. [English version: Lord George Gordon Byron. Childe Harold's Pilgrimage (98). Kindle Edition]

${ }^{23}$ Juano, Eduardo. Cirlot, "Kybele," in Stownik symboli, trans. Ireneusz. Kania (Krakow: Znak, 2000), 217-218.

${ }^{24}$ Byron, Wędrówki Czajdl Harolda, Canto IV, 568, line 11.

${ }^{25}$ In the notes to Childe Harold's Pilgrimage, Byron indicated a relationship between the image of Venice/Cybele and the image of Marcus Sabellicus, the author of Venice's history Historiae rerum venetarum ab urbe condita, who supported a particular point of view: "whoever views the city from above shall think they are seeing an image of the earth filled with towers, drawn in the depths of the ocean," (Wędrówki Czajdl Harolda, note 2, 626). By formulating the following image: "ever since the mouldy Venice with its hairdo of bell towers, a marble forehead and golden wrinkles has been the object of sales and trade as if some parcel with its former goods," ("Księga o Wenecji," trans. Paweł Hertz, Zeszyty Literackie, issue 39 (1992): 85), referred to Byron's portrait of Venice in Canto IV of Childe Harold's Pilgrimage. That "hairdo of bell towers" referred to the image of Cybele: "Rising with her tiara of proud towers," (Wędrówki Czajdl Harolda, 568, line 11). 
it as Cybele not only because in the Roman tradition she was considered a protector of cities, but probably because phonetically the name Cybele resonated well the "la bella," Venice's nickname. One could also assume that he chose her because she was celebrated by the Greeks as mother nature. Therefore, he might have associated Venice/Cybele with the archetypal mother. ${ }^{26}$ Traces of that kind of association can be found in Childe Harold's Pilgrimage. Byron wrote about it in a very personal manner: "I fell in love with it when I was still very young," and he suggested a kind of internalisation: "And Otway, Radcliffe, Schiller, Shakespeare's art, / Had stamped her image in me." ${ }^{27}$ But he also matched the aura of a fable: The city of Venice, "as if a fairy abode." ${ }^{28}$ That way he breached the official image consolidated in painting in favour of a more personal one, certainly bearing some rooting in Ann Radcliffe's vision of enchanted city (The Mysteries of Udolpho).

Odyniec transformed Byron's fabled thread into that of a ballad. Cybele, the "lady of the sea depths," became in his version a siren, an inhabitant of waters in Romantic ballads. The author awkwardly pieced together her "body" from the fragments of the city's space. He wrote about the unusual relationship of elements, which: "in the centre and on the city's limbs (...) are as if a siren's 'fish underbelly,' while Piazza di San Marco is her torso and heart, and Piazzetta is her charming delightful little face."${ }^{29}$ By proposing that topography of the city, Odyniec followed an already consolidated cultural trail. ${ }^{30}$

One could say that with the author of Don Juan, a trend began of developing Venice's artefacts, which became attempts at breaking image-based stereotypes. In Romantic and post-Romantic literature, it was constantly being assigned new names and images - from stereotypical, through pretentious, to surprising ones. Odyniec also indicated the most popular one, i.e. "They compare Venice to the Venera being born of sea waves"; $; 1$ Chateaubriand called it "the Adriatic's wife" and "the master of the seas." ${ }^{\prime 2}$ The search for the appropriate image for Venice was continued in modernist literature,

${ }^{26}$ That remained in line with the climate created by folk songs, in which the city was considered a mother. One could also indicate other traces. Venice was presented as Madonna, vide Peter Ackroyd, Wenecja. Biografia, trans. Tomasz Bieroń (Poznań: Zysk i S-ka, 2015), 283-284.

${ }^{27}$ Byron, Wędrówki Czajdl Harolda, Canto IV, 573, lines 158-159.

${ }^{28}$ Ibid., Canto IV, 573, line 155.

${ }^{29}$ Odyniec, Listy z podróży, vol. 1, 403.

${ }^{30}$ It is unclear how intentional was Odyniec's use of the patterns consolidated in culture of the comparison of the space of Venice to a living organism. Peter Ackroyd indicated that "By the sixteenth century it was already being described as a human body where «the head is the place where the shores are situated; and that part towards the sea are the arms.» The canals were the veins of the body. The heart lay in the city itself. So wrote Cristoforo Sabbadino in 1549. The English traveller, James Howell, said that no foreign prince had ever "come nere her privy parts.»" Yet he did not indicate in which of Venice's areas he placed them. The author of Venice suggested that "they were presumably the ducal palace and the basilica." (Ackroyd, Wenecja. Biografia, 217 [English version: Peter Ackroyd, Venice. Pure City (New York: Random House, 2009]). Odyniec invented for Venice the shape of a siren's body, the topography of which he transferred onto slightly different spaces of the city than Sabbadino or Howell.

${ }^{31}$ Odyniec, Listy z podróży, vol. 1, 514.

${ }^{32}$ François Renè de Chateaubriand, Pamiętniki zza grobu, selected, trans. and commentary by Joanna Guze (Warsaw: PIW, 1991), 555. 
a fact which was aptly noted by Dariusz Czaja. ${ }^{33}$ He indicated the creations by Joseph Brodsky, Ezra Pound, Gustaw Herling-Grudziński, and more. Apart from conventional images, i.e. of Venera, the goddess of love and beauty, associated with Venus and Greek Aphrodite (Pound and Oskar Miłosz), he also indicated some less trivial propositions. For example, Fernand Braudel presented Venice as Penelope, Joseph Brodsky saw in Venice "Greta Garbo in a swimming pool," and Aleksander Wat called it "an old dangerous witch that settled on the sea." ${ }^{34}$ One could argue that specification of the image of Venice became an essential motif in both travel narratives and poetry - accounts of experiencing the city. In the 19th century, Odyniec chose a siren. Why did he choose it? I shall return to this question later in the text.

\section{Death in several versions}

Odyniec offered an ambiguous presentation of his experience of "the queen of the Adriatic." On the one hand it charmed him, he was nearly petrified in awe. Yet, on the other, he indicated, like many other travellers, the clearly felt contradicting nature of impressions, a fact he conveyed in a particular image: "Today's Venice is akin to a senile dethroned monarchess who at first glance would seem a pitiable old lady, but wait until she opens her treasure chests - you will immediately feel what she once was and you shall bow once again before her like when in the glow of her majesty and charm she accepted visitors at her throne." 35

When outlining Venice's image, he referred to patterns consolidated in travel narratives, and invoked its two faces, both being image-based clichés. One was modelled from the matter of St. Mark's Square often referred to as the ballroom or parlour of Europe (Napoleon). In literature, it was commonly depicted in a night-time mood: lit up by the moon ${ }^{36}$ and gas lamps ${ }^{37}$. The other was formed from the impressions arising from wandering the labyrinth of narrow streets and canals - dark and shocking with their ugliness. Odyniec recorded the outline of the following sight:

In fact, that downfall is visible here everywhere except in St. Mark's Square, which is full of life of the new style, and in Piazzetta, from where the images are always the same. Everywhere else the grander a square, palace, $149-151$.

${ }^{33}$ Dariusz Czaja, “Wenecja jest kobietą. Rzecz o wyobraźni,” Konteksty, issue 3/4 (1995):

${ }^{34}$ Aleksander Wat, Korespondencja, selected, ed., notes and introduction Alina Kowalczykowa (Warsaw: Czytelnik, 2005), vol. II, 642.

${ }^{35}$ Odyniec, Listy z podróży, vol. 1, 411. Chateaubriand offered a similar portrait of Venice, vide note 19. One could assume that by using the adjective "senile" in reference to Venice, Odyniec was "zgrzybiała" meaning "mouldy, resembling an old mushroom"].

Ann Radcliffe, Tajemnice zamku Udopho. Romans strofami poezji przetykany, trans. Wacław Niepokólczycki. Illustrations by Roman Cieślewicz (Warsaw: PIW, 1977), vol. 1, 194, invoked an image-based cliché [the word he used in Polish was "zgrzybiała" meaning "mouldy, resembling an old mushroom"].

${ }^{36}$ Ann Radcliffe, Tajemnice zamku Udopho. Romans strofami poezji przetykany, trans. Wacław Niepokólczycki. Illustrations by Roman Cieślewicz (Warsaw: PIW, 1977), vol. 1, 194.

${ }^{37}$ Eucja Rautenstrauchowa, W Alpach i za Alpami (Warsaw: Merzbach, 1850), vol. 3, 218. 
or official building, the sadder the sense of emptiness, abandonment or filth. For example, this stretch of palaces along the banks of the Grand Canal, all facing it, with delicious colonnades, galleries, and staircases the last steps of which sink in water, the whole line of palaces, I tell you, resembles a line of skeletons in a morgue; they are just as badly deprived of any pretence of life and "from their huge windows destruction peers" so strongly that their putrid coldness covers even the stench and mould of the canal. During the day, the majority of the windows have their blinds closed or are simply boarded up; in the evening, there is not a single light in either of them and only those on Rialto Bridge reflect the lights illuminating the stores in the black waters of the canal spread along both sides of the bridge. On the grandest of galleries, once probably covered in carpets, from which elegant beauties peered keenly onto the canal, today here and there are underwear drying. In the staircases of Carrara marble, once swept with the togas of doges or long dresses of signiorinas, you can simply see rubbish or decaying weeds which the water has carried. Maybe in a different season when their richer owner currently spending time in villages shall return to the city, maybe this part of the city shall also look more lively and joyfully, but for now no cemetery could offer a grimmer statement about the triviality of the objects of this world. ${ }^{38}$

In the quoted fragment, destruction and overwhelming emptiness exist side by side with a mental projection of the city's past glory. Similarly to Radcliffe, Byron, and Chateaubriand, the author used contrastive combinations: imagined traces of grandness and actually perceived ruin. The clash between the images was supposed to emphasise the mechanism of metamorphoses, i.e. creation and destruction, which Venice underwent. Odyniec assigned the ruin a clearly Gothic shape: he transformed a "stretch of palaces" into "skeletons in a morgue." He supplemented other mental projections with actual observations. He wrote about rotting weeds, rubbish, and filth..$^{39}$ He invoked experiences which suggested decay: he referred to the scent of mould and of rotting plants as "putrid coldness." He also utilised realistic descriptions filled with ugliness: he indicated boarded-up windows and underwear drying on lines, which in his perception were supposed to prove the degradation of the city. ${ }^{40}$ For him, those "skeleton palaces" spreading a putrid stench resembled the mortal dimension of the city.

${ }^{38}$ Odyniec, Listy z podróży, vol. 1 , 410-411.

${ }^{39}$ On rubbish and filth in Venice vide Goethe, Podróż włoska, 82.

${ }^{40}$ Chateaubriand accurately exposed the ruin spreading through Venice: "When you see a trowel with mortar and gypsum being laid hastily on a damaged marble capital, you are overcome with dread. I'd prefer worm-eaten boards covering Greek and Mauritanian windows and tatters drying on exquisite balconies to the touch of the powerless hand of our century," Chateaubriand, Pamiętniki zza grobu, 556.

It seems, however, that the underwear drying on the lines in Odyniec's description had nothing to do with the ruinous degradation of the city. As proof consider 18th-century cityscapes where the "hanging rags" were treated as an element of the peculiar beauty of the city and its character, vide The Grand Canal, Looking North-East from Palazzo Balbi to the Rialto Bridge (around 1720) by Antonio Canal commonly known as Canaletto. There is, however, a subtle difference in Chateaubriand's descriptions as he indicated that those "rags" hang on 
Odyniec did stop there. He did not relate the ruin he saw to the frailty of human existence or to the generational experience of "being a ruin." He did not treat it as a form conceptualisation of an autobiographical myth. ${ }^{41}$ That motif of a spiritual relationship with Venice's ruins was, however, indicated by Byron: "It [Venice - A.K.] has not disappointed me; though its evident decay would, perhaps, have that effect upon others. But I have been familiar with ruins too long to dislike desolation." ${ }^{\prime 2}$

Venice, as indicated in the works by the author of The Giaour, became for him an autobiographical space, a space for new roots, if you will, through the breaking away from his former one, i.e. English. One should note that it was Byron who introduced the topic of catastrophe in literature - the image of the death of Venice, the "city on water," which in the future of his vision would be drowned in the Adriatic. As the threat continued to increase, the motif indicated in "Ode on Venice" became extremely popular in art. ${ }^{43}$ In contrast, Odyniec followed a Gothic path established at that time. He did not yield to the melancholic beauty envisioned by Chateaubriand: "Venice is here, she sat on the sea shore as if a beautiful woman who is going to fade as the day; the evening wind is playing with her fragrant hair; she is dying: the whole charm and all smiles of nature have come to bid her farewell."'44 In Odyniec's view, Venice was dying like any other city which lost its life's powers. He was not delighted in the process of becoming a ruin/skeleton. He did not associate ageing/ "senility" with beauty but rather with walls crumbling, plaster peeling off, mould spreading, and the omnipresence of rot and filth.

\section{Regarding the past}

Odyniec enriched aesthetic admiration for Venice combined with a reflection on its degradation with a highly distanced and critical reflection about its past. He referred to a historian by the name Pierre Daru. ${ }^{45} \mathrm{He}$ single-sidedly argued:

(...) w całym Daru, niestety, nie wyczytałem ani jednego wypadku, w którym by się ten symbol kupieckiej Rzeczypospolitej lwią czy orlą

the exquisite balconies of palaces. Odyniec failed to notice that subtle detail, even though he probably drew inspiration from Chateaubriand's description.

${ }^{41}$ Grażyna Królikiewicz, Terytorium ruin. Ruina jako obraz i temat romantyczny (Krakow: Universitas, 1993), 104-109.

${ }^{42}$ Byron, "List do Thomasa Moore'a, Wenecja 17 listopada 1816," in Listy i pamiętniki, 166. [English version: https://lordbyron.org/monograph.php?doc=ThMoore.1830\&select=AD1816.34] In his memoir, journal, and letters one could indicate numerous ruin-related reflections: "I passed an entire forest of dried pines, completely dried up; naked trunks, bark torn off, dead branches; it all happened in one winter - at that sight I thought of myself and my family." Byron, "Dziennik dla Augusty," in Listy i pamiętniki, 492.

${ }^{43}$ In Polish literature, the motif of death by drowning appeared, e.g. in a novel by Wacław Kubacki entitled Smutna Wenecja (Warsaw: Czytelnik, 1968).

${ }^{44}$ Chateaubriand, Pamiętniki zza grobu, 557.

${ }^{45}$ Pierre Daru, Historie de la Républiqe de Venise (Paris: Firmin Didot, 1819); a multi-volume opus to which Lord Byron also referred. It was also read by Zygmunt Krasiński. 
wspaniałomyślnością odznaczył i na wdzięczność ludzkości zasłużył. Darmo mówić, ale miecz, który jest zarazem i łokciem, nigdy mieczem Temidy nie będzie i prędzej może chyba gwicht jej szali sfałszuje. Toteż bodaj że upadek Wenecji sprawił w świecie raczej wrażenie bankructwa możnej i odwiecznej firmy niż upadek wielkiego narodu i państwa. ${ }^{46}$

[sadly, nowhere in Daru's work have I found a single instance where the symbol of the mercantile Republic had proven its lion's or eagle's generosity deserving people's gratitude. Needless to say, a sword which is also an elbow can never become Themis's sword and all it could do is distort a weight of her scales. That is probably why Venice's downfall was considered by the world as the bankruptcy of an affluent and perennial firm rather than the fall of a grand nation and state.]

It seems that that mercantile character in his perception deprived the city on the lagoon the prestige of a grand nation and state. That is because in the imagined world of Polish szlachta, the fact of being a merchant was not aligned with such values as glory and bravery. One could suspect that his xenophobic attitude prevented him from developing a reflection resembling that of Chateaubriand who had no doubt that Venetian merchants were also knights. ${ }^{47}$ In actuality, as suggested by Ackroyd, "The image of the merchant is central to any understanding of Venice." ${ }^{\prime 48}$ Odyniec did not make that effort as he probably could not imagine that someone wealthy could also strive for glory. In his memory, he retained the "merchant/military Republic of Venice" in which "meaningful and resonating words were no profitable goods." ${ }^{\prime 9}$ As he visited the Doge's Palace, he was not fascinated by the splendour and grandness of the interiors nor the art displayed there, which hailed the city's history and the victorious wars of its inhabitants. He did not, like Byron in Childe Harold's Pilgrimage, admire the battle of Lepanto, nor did he call Venice "Europe's stronghold against the Ottomans." ${ }^{20}$ He did not write about its glory as Wordsworth ${ }^{51}$ or Shelley ${ }^{52}$ did.

It seems there were at least a few reasons for Odyniec's different perception of Venice's past. One might assume that he easily succumbed to patterns of thinking and of the visions which shaped reflections on Italian, and Venetian, nationality. He might have adopted it from Madame de Staël,

${ }^{46}$ Odyniec, Listy z podróży, vol. 1, 410.

${ }^{47}$ Chateaubriand, Pamiętniki zza grobu, 556.

${ }^{48}$ Ackroyd, Wenecja. Biografia, 118.

${ }^{49}$ Odyniec, Listy z podróży, vol. 1, 427.

${ }^{50}$ Byron, Wędrówki Czajdl Harolda, Canto IV, 572, line 123.

${ }^{51}$ In "On the Extinction of the Venetian Republic," William Wordsworth wrote: "the worth/ Of Venice did not fall below her birth,/ Venice, the eldest Child of Liberty," in Angielscy "Poeci jezior" William Wordsworth, Samuel Taylor Coleridge, Robert Southey, selected, trans., introduction and commentary by Stanisław Kryński (Wrocław-Warsaw-Krakow: Ossolineum, 1963), 35.

${ }^{52}$ Percy Bysshe Shelley also offered a grandiloquent image of Venice: "And the beams of morn lie dead/ On the towers of Venice now,/ Like its glory long ago" "Lines Written among the Euganean Hills," in Poezje wybrane, selected, ed. and introduction Juliusz Żuławski (Warsaw: PIW, 1961), 41). 
who depicted Italians in a negative manner when she wrote in Corinne, ou l'Italie about their weakness, cowardice, lack of national pride, and ignorance. ${ }^{53}$ Similarly spirited remarks were offered by Lamartine in The Last Canto of Childe Harold's Pilgrimage. ${ }^{54}$ Their poor will to fight was also indicated by Napoleon. Yet Odyniec's historical reflections were influenced not only by the stereotype popular in the 19th century. His negative attitude towards Venice the state could have also resulted from religious issues, and its relationships with the papacy in particular. It is a fact that it defended the autonomy of the local church and it often refused to submit to the Holy See. Surely Odyniec, a Catholic, found it difficult to forgive some of its decisions, e.g. the fact of using crusade knights to fight for the Republic's own interests. Most certainly for that reason he did not conceal his attitude towards Venetians' religiosity. When writing about the statues of Neptune and Mars on top of the stairs leading to the Doge's Palace, he argued that Venice "served more at heart those two Pagan patrons than the saint Evangelist." 55 It was not only his religious conservatism and the narrow-mindedness of his szlachta way of thinking that forced Odyniec into such an unequivocally negative attitude towards Serenissima. He was also offended by wealth so ostentatiously displayed in the Doge's Palace. He did not admire it as Chateaubriand did who wrote: "In the Doge's Palace there are wondrous things hall after hall." ${ }^{\prime 56}$ The author of Memoirs from Beyond the Grave, an aristocrat accustomed to interior luxury, did not lose his desire to admire beauty based on historical knowledge. He wrote: "The bridge is entrancing from the outside, the façade of the prison is admirable: not even tyranny or tragedy could exist without beauty in Venice." ${ }^{\prime 57}$ Odyniec chose a different style: "Suffice to consider the Doge's Palace (...) Surrounded by a wall, wonderful in structural terms yet always resembling that of a monastery or a fortress, with a lion's mouth always opened, as if forever in a roar and hungry, at the entrance, into which denunciations were once tossed." ${ }^{58} \mathrm{He}$ thus described the palace's interior:

Then, the earthly glory of Venice shines right next to it in the brightest of colours. Those include large and small on the walls and on the ceiling and in this and in further halls paintings of battles, victories, triumphs and homages which the Republic achieved and received through its servants, enslaving and pillaging without restraint: Greeks, Turks, Saracens, and its righteous compatriots and neighbours. It itself in apotheoses by the greatest masters appears several times as a goddess surrounded by a supernatural glow and as a personification of all Pagan and Christian virtues.

\footnotetext{
${ }^{53}$ Germaine de Staël, Korynna czyli Włochy, trans. Łucja Rautenstrauchowa, Karol Witte, ed. by Anna Jakubiszyn-Tatarkiewicz (Wrocław-Warsaw-Krakow: Ossolineum, 1962).

${ }^{54}$ Ostatnia pieśń pielgrzymki Childe Charolda z Lamartine'a, trans. Adam M-ski [Zofia Trzeszczkowska] (Vilnius: Józef Zawadzki, 1883).

${ }^{55}$ Odyniec, Listy z podróży, vol. 1, 428. Because Venice held the relics of St. Mark the Evangelist, it was considered as the capital of European Christianity.

${ }^{56}$ Chateaubriand, Pamiętniki zza grobu, 558.

${ }^{57}$ Ibid., 560.

${ }^{58}$ Odyniec, Listy z podróży, vol. 1, 427.
} 
Those only remain that which they originally were, that is painted things, though maybe if they actually existed in its life, the city itself would be more than just a painting. ${ }^{59}$

Significantly, Odyniec had no enthusiasm for the beauty or grandness of the art he viewed in the Doge's Palace as he did not respect Venice's features. One can only assume that his aversion mainly resulted from imperial policy, and it, in the perception of the author of Listy, deprived the city of its "virtues," as they were, as he wrote, only "painted." It was their absence that caused, in his mind, the eventual failure of the Republic, which in Odyniec's text was only reflected in the black two-headed Austrian eagle, the symbol of contemporary enslavement, placed over a winged lion over the entry gate to the Arsenal. In the reflections of the narrator of Listy, there is no compassion for the very recent tragic events in the history of the city-state.

As he wrote about the former queen of the Adriatic, he revisited Gothic motifs. He submitted to 19th-century visions of Venice as a city of dread ${ }^{60}$ It seems that by introducing a story of the prison into his travel narrative, he also utilised it for forming the Gothic image of the city. He meticulously described its location. He wrote about its space, torture devices, and the methods of murdering convicts. He exposed the brutality of those who yielded power reminding readers that Poland was free of such deeds. He amplified the negative attitude towards the city's history referring to the poetics of terror via a special kind of theatralisation of the space around the Doge's Palace. In the short story, he offered the image of doge Marino Faliero's severed head rolling down the "stairs of giants." He made references to actual events consolidated by Byron in the historical tragedy Marino Faliero, Doge of Venice. A projection of the image of a slaughter - a penal spectacle in which the body became the main object of repression was, according to Odyniec's intentions, a kind of disgrace of the city-state, a proof of its barbarity. The author's imagination inscribed the figure of Faliero into the referenced interiors of the Doge's Palace as if branding its entire space with the memory of the events. Thus, the projection became an expression of the narrator's negative attitude towards Venice's past and its politics. The author of Listy $z$ podróży did something else, too. He usually refrained from indicating Mickiewicz's reactions. This time was different. He discussed at length how Mickiewicz refused to examine the torture devices as they filled him with disgust, just like the entire prison space. That was the only situation when he exposed the poet's somatic experiences. It seems that Venice's imperial nature, which deprived other nations of their freedom, in combination with brutal acts of tormenting convicts triggered Mickiewicz's disdain, an emotion which was shared by Odyniec: “The Doge's Palace evokes no sympathy, apart from some admiration for its architectural beauty, and it is truly repulsive if one considers its history." ${ }^{\prime 1}$

${ }^{59}$ Ibid., 429.

${ }^{60}$ Ackroyd noted that in the 19th century there was a strong trend to promote the myth of Venice as a dark and diabolical city, see Wenecja. Biografia, 94.

${ }^{61}$ Odyniec, Listy z podróży, vol. 1, 428. 
Odyniec remained indifferent to the fable-like vision of Venice offered by Radcliffe, the image of Venice the mother proposed by Byron or the melancholic portrait of dying Venice by Chateaubriand. The artefact he developed was influenced by the cultural pattern of Gothicism. Interestingly enough, however, his use of image-based clichés did not prevent him, it would seem, from capturing an authentic experience - that disdain of the city and its authorities which utilised violence.

\section{A tower view}

Disapproval, disdain, and disgust were expressed and proven in the image of Venice developed by Odyniec as viewed from Saint Mark's Clocktower. The author followed well-worn trails. It is clear that the viewing of the cityscape from the top of the tower was particularly popular not only among 19th-century travellers. For example, Madame de Staël noted that Venice had been built on a completely flat surface "on which church towers seem surrounded by water like the masts of motionless ships." ${ }^{\prime 2}$ One should also remember the passage that inspired Lord Byron. In the notes to Childe Harold's Pilgrimage, he referenced the imaginary projection by Marcus Sabellicus in Historia Wenecji: "Whoever views the city from above shall think that they are viewing the image of the earth filled with towers outlined in the depths of the ocean." ${ }^{63}$ Odyniec and Mickiewicz surely remembered that image as they both returned to reading Byron as they travelled through Italy. Yet the sight from St. Mark's Clocktower presented by Odyniec had nothing in common with that of Sabellicus:

\footnotetext{
A na wodzie, u stóp wieży,

Gród wenecki plackiem leży

Jak żółw czarny, jak kłąb zwity

Lewijatan, lupu syty,

Co śpiąc, zda się,

Śni o czasie,

Gdy dźwignąwszy kadłub smoczy,

Na galerach, jak na skrzelach,

Z Zary Niemcom bryzgał w oczy,

Ogniem zionąc w Dardanelach!

A dziś - a dziś! Śpij, nieboże!

I bez ciebie świat żyć może ${ }^{64}$
}

\author{
And on water, at the tower's feet, \\ The Venetian city lies flat \\ Like a black turtle, bundled like a cloud \\ Leviathan, filled with spoils, \\ While sleeping, it seems, \\ It dreams of a time, \\ When it lifted its dragon's body, \\ On galleys like on gills, \\ Suddenly sprayed Germans in the eyes, \\ With fire spewing in the Dardanelles! \\ And today - oh, today! Sleep, poor \\ [thing! \\ The world can go on without you.
}

He was rather inspired by the image offered in Madame de Staël's Corinne, who looked towards Dalmatia and Istria, like Odyniec towards Zadar, which were enslaved by Venice. It seems that in the perception of the Polish traveller, the city-state's invasiveness was considered loathsome as

\footnotetext{
${ }^{62}$ Staël, Korynna, czyli Włochy, 401.

${ }^{63}$ Byron was inspired by that sight as he developed the portrait of Venice the Cybele.

${ }^{64}$ A.E. Odyniec, Listy z podróży, vol. 1, 432-433.
} 
this time he did not refer to Venice as a siren by rather a leviathan - a demonic sea monster, a serpent or a dragon with several heads that "sprayed into the eyes" and "spewed fire." Therefore, Odyniec referred to the Old Testament and the personifications of devilish powers. ${ }^{65} \mathrm{He}$ developed a new ethically questionable image of Venice by using a moralising interpretation. He subordinated the sight from the tower to this moral inclination - its framework, though, was not defined by his perception but his emotional evaluation. That is why the subjectivisation of the description did not result in an eyewitness nature by a generalised vision which assumed the form of an allegory of the city as a monster, a leviathan. ${ }^{66}$

It seems that Mickiewicz shared Odyniec's disapproval of the historical role of Venice. That is evident not only when one considers the former's disgust at torture devices and the prison but also the poem "Morlach w Wenecji" which was presumably written between 1827 and 1828. The poet was inspired by a text in a collection published by Prosper Merimee and he converted it into a poem being certain of its originality and the author's Serbian provenance. ${ }^{67}$ Thus, he could treat it as an authentic complaint of a Slav ${ }^{68}$ who believed the stories of the rich Venice and sailed to it hoping for turning his wretched fate. Yet the myth of the fable city that shared gold with foreigners was soon shattered. The poet exposed the dramatic situation of foreigners in the Venetian world. He gave voice to a protagonist who offered a sharp depiction of the experience of being uprooted: "I am like a tree replanted in summer,/ The sun shall burn it and the wind shall blow it away," ${ }^{\prime \prime 9}$ and the sense of the insignificance of his existence: "I am but an ant raised in the forest,/ Tossed by the wind in the middle of a pond!"70 The Slav's confession can be treated as an accusation aimed at the state's policy and its ruthlessness towards those who served it. In that lyrical/

\footnotetext{
65 See Władysław Kopaliński, "Lewiatan," in Słownik symboli (Warsaw: Wiedza Powszechna, 1990), 196-197.

${ }^{66}$ The myth of the city/monster/Leviathan was discussed by Czesław Miłosz who mostly referred to Balzac's prose, see "Legenda miasta-potwora," in Prywatne obowiazki (Olsztyn: Pojezierze, 1990), 189-197.

${ }^{67}$ Publishers explained that "Morlach w Wenecji" was a translation of an in-authentic song taken from a collection published by Prosper Mérimée entitled La Guzla on Choix de poesies illyriques, recuellies dans la Dalmatie, la Bosnie, la Croatie et l'Herzgovine - in English: a selection of Illyrian poetry collected in Dalmatia, Bosnia, Croatia and Herzegovina, (Paris: F.G. Levrault, 1827). It was only in 1935 that Mérimée admitted that the collection was a mystification. See Adam Mickiewicz, Dzieła. Wiersze ed. Wacław Borowy, Eugeniusz Sawrymowicz (Warsaw: Czytelnik, 1955), vol. 1, 642. While visiting Venice in 1829, Mickiewicz could have known about that. It was only during the 22nd lecture of the first lecture on Slavic literature (19 Mar 1841) that he indicated the fact: "The author openly admitted deceit. He stated that he did intend to depart on a journey through Slavic states yet he thought that it would be much easier to provide a description of the journey, sell it to booksellers only to later, using the money thus made, make the journey and find out about the difference between the reality and his imagination," (Adam Mickiewicz, Literatura słowiańska. Kurs pierwszy. Pótrocze I, trans. Leon Płoszewski (Warsaw: Czytelnik, 1955), vol. VIII, 297-298).

${ }^{68}$ Morlach - Italians used the word to denote Adriatic Slavs, mainly Dalmatians, see Adam Mickiewicz, Dzieła. Wiersze, vol. 1, 641.

${ }^{69}$ Mickiewicz, "Morlach w Wenecji," in Dzieła. Wiersze, vol. 1, 311-312.

${ }^{70}$ Ibid.
} 
dramatic story, Venice was presented as "a rock-hard ship."71 That is an obvious reference to the city's location on water and the image-based clichés existing in literature. Yet the name assumed a symbolic meaning as a space in which one could not find help or compassion. The only thing that the protagonist experienced was an endless sense of alienation, captivity, being uprooted, and an overwhelming sense of the paralysing frailty of human existence being crushed under the pressure of an indifferent world. The need to translate the quasi-Serbian record uncovered not only the poet's keen interest in the tragic history of Slavs, but also the indifference of the world to that evil. The poem proves his sensitivity to the fates of others. ${ }^{72}$ In 1829, Mickiewicz had the opportunity to discover for himself the sources of the myth of golden Venice. As he walked the golden stairs of Palazzo Ducale and as he strolled through its halls, he realised the extent of the past wealth of the city, the essence of which was and has been ever since the space inside the Palace. His reaction, revealed by Odyniec, to prison stories proved Mickiewicz's solidarity with the harmed and the hurting. Therefore, one could assume that the Doge's Palace remained both in the mind of Mickiewicz and his travel companion a space filled with wealth yet commonly associated with the endless pride of its authorities and the misery of Slavs who served it. ${ }^{73}$

It is possible that the negative image of Venice emerging from Odyniec's text was also influenced by the anti-urbanism message deeply rooted in the Polish traditions of landed nobility and the imagined world of the szlachta. It emerged, as it is widely known, from the negative evaluation by Polish 19th-century thinking and literature of cities, which, in contrast to rural areas, were considered as amoral and contemptible. By utilising the allegorical image of a leviathan city, Odyniec perpetuated the anti-urbanism myth. However, his relationship with municipal spaces does not seem obvious. He did undertake some - albeit feeble - demythicising gestures, ${ }^{74}$ modifying the image of Venice in order to temper the image of the monster city which he created himself. That might have been a result of the "contradiction of impressions" which he himself indicated. That view was also surely influenced by the status of the traveller who wandered the city to

${ }^{71}$ The motif of a ship appears in Corrine: Venice "is neither a ship because it remains in one place motionless" (401). Odyniec referred to Mickiewicz's metaphor of Venice writing: "It is a strange city, resembling both a rock fleet and a labyrinth," (Listy z podróży, vol. 2, 171).

${ }^{72}$ Literary historians have indicated that "Morlach w Wenecji" could also be treated as a projection of the poet's Russian experience. Juliusz Kleiner thus wrote about Morlach: "it is part-Pole in Moscow or Petersburg, where he does not feel 'any free throught or free movement' and where 'even compatriots assumed the language and new customs,'” see Juliusz Kleiner, Mickiewicz, vol. II, part I (Lublin: Towarzystwo Naukowe KUL, 1948), 130.

${ }^{73}$ Krystyna Poklewska, the author of a study of Mickiewicz's translations, highlighted a major issue. She indicated that "Morlach w Wenecji" was included between among the translations of works only by acclaimed authors: Goethe, Shakespeare, Pushkin, and Dante. On that basis, one could argue that Mickiewicz thought highly of the poem proclaiming in it his disapproval of evil, this time of the Venetian world. Krystyna Poklewska, "Mickiewicz i Mérimée. Z dziejów dwóch wierszy Mickiewicza," in Obrazki z romantyzmu. Szkice o ludziach, tekstach i podróżach (Łódź: Wydawnictwo Uniwersytetu Łódzkiego, 2016), 12-14.

${ }^{74}$ See Elżbieta Rybicka, "«Gesty demityzacyjne»," in Modernizowanie miasta. Zarys problematyki urbanistycznej w nowoczesnej literaturze polskiej, 71-80. 
discover it following his guide's direction. He used conventional knowledge onto which he applied his own experience rooted in "familiarity." Thus, he somewhat tamed the urban space, maybe not conquering but at least slightly disrupting the anti-urbanism decorum. Maybe that was the source of that peculiar mixture of moralising interpretation with a special kind of "naturalisation." That was surely possible because the image of Venice had little in common with that of a typical city. Its inherent lack of traffic and the quiet of the labyrinth of the narrow streets and canals placed it at a fringe. Maybe that was the reason why Odyniec indicated the instances of nature within the urbanised space. It is uncertain whether he noticed the sea-like uneven floor of St. Mark's Basilica but he most certainly noted the various architectural elements which referred to nature; for example, he recorded that the church was filled "with sculptured leaves or flowers." ${ }^{175} \mathrm{He}$ might have noticed the capitals of the Doge's Palace with dolphins, crabs and shells; he did notice the crocodile being tamed by St. Theodore. He consciously focussed on the rhetorical power of his text. He chose particular comparisons. The ships he saw "setting their white sails" were as if "swans or geese"; he thus described Saint Mark's Basilica which according to him "was completely like a king lion": "There is truly something of a lion in it. It does not seem to be rising into the air like, e.g. Gothic cathedrals, but the very first moment you glance at it you are astonished by how grandly, how strongly it sits on the ground. Its very face is that of a lion with a thick mane, just watching you, as if with its lion's eyes, that is how much you admire it with respect and admiration as if in fear." ${ }^{\prime \prime 6}$ He referred to Venice as a leviathan but also a "black turtle"; he also utilised common image-based stereotypes, e.g. the comparison of the Grand Canal to a serpent: "it twists like a boa in an irregular $\mathrm{S}^{\prime \prime} ;{ }^{77}$ he stereoty pically compared gondolas to coffins, ${ }^{78}$ but also to birds: "like water ravens black in a thick flock glistening with their light beaks,"79 or "like swallows all alike," "like a swallow in the air seeming to be rocking without a trace." ${ }^{\prime 80}$ Odyniec devoted much attention to the local pigeons. That was nothing original as stories about them were part of the canon of the city's descriptions. It is noteworthy that he did not devote that

\footnotetext{
${ }^{75}$ Odyniec, Listy z podróży, vol. 1, 408.

${ }^{76}$ Ibid., 407-408.

${ }^{77}$ Ibid., 410.

${ }^{78}$ In Venetian Epigrams, Goethe formulated a long-lasting image of gondolas:

I would liken this gondola unto the soft-rocking cradle.

And the chest on its deck seems a vast coffin to be.

Yes! 'tween the cradle and coffin, we totter and waver for ever

On the mighty canal, careless our lifetime is spent

Johann Wolfgang Goethe, Epigramy weneckie. Venezianische Epigramme, selection and trans. Piotr Wiktor Lorkowski (Krakow: Miniatura, 1999), 15. [English version: Goethe J.W., The Works of J.W. von Goethe, Volume 9, https://en.wikisource.org/wiki/ The_Works_of_J._W._von_Goethe/Volume_9/Venetian_Epigrams]

Madam de Staël adopted that vision from Goethe: "Those black gondolas which glide on the canals are like coffins or cradles, like the last and first of man's abodes," (Korynna, czyli Wtochy, 401 [English version: Madam de Staël, Corinne, or Italy, (Oxford: Oxford University Press, 2008)]). Eventually, the coffin gondola became the most popular.

${ }^{79}$ Odyniec, Listy z podróży, vol. 1, 409.

${ }^{80}$ Ibid., 417.
} 
much attention to any of Venice's historical sites as he did to them: "crowded in flocks they take a siesta on roofs, copulas, towers and church crosses or, like swallows back home, under the ceilings of palace galleries they nest and rock freely." ${ }^{\prime 1}$ He used a pigeon story to develop a kind of a metaphor of Venetian space viewed in a new version: that of a dovecote. His less fortunate attempt at naturalising the city was the description of the fish market located under the Rialto Bridge. Goethe was charmed with what he saw there. Odyniec embarrassed himself because of his lack of knowledge: "Imagine a black ever-moving pile of the most disgusting of tiny creatures: frogs, beetles, snails, spiders, and scorpions." 82 The Polish traveller was not interested in the special character or the qualities of the place. He focussed on that which was familiar, e.g. pigeons. He proved his lack of openness for the experiences gained while visiting Venice, though, eventually, not a complete lack as, e.g. he twice indicated a Venetian concoction called "theriac." 83

All the procedures used for taming urban settings were supposed to lead to a rusticalisation of space, to blurring its foreignness. That is visible in the choice of stories. Odyniec found space for a story of his visit to a public garden ${ }^{84}$ or a visit to Ms Baeder at her hospitable home, as if at a Polish manor. The fact of indicating a conversation with Mickiewicz also seems significant:

(...) poszliśmy jeszcze na Piazzettę i usiadłszy na wschodach pogawędziliśmy z godzinę. Fale pod lekkim wiatrem rozbijały się z szumem u stóp naszych. Adam mówił o głosach natury i utrzymywał, że w nich jest pierwszy kamerton i zasada wszelkiej harmonii, miary i rytmu - tak w muzyce, jak i w poezji. (Monotonny plusk fal jednych po drugich, i to w regularnych przestankach, zdawał się być wzorem aleksandrynów francuskich.) Gdybyśmy mogli i umieli wsłuchać się dobrze w śpiew ptaków, dostrzeglibyśmy i tam to samo prawo. W śpiewie ptaków podlatujących nad ziemię zaczyna się poezja, głos czworonogów - to proza. Śpiewają właściwie ptaszątka tylko leśne i polne, i to małe, szare, niewinne. Bełkocą tylko duże i czarne, jak cietrzew, głuszec, indyk itd. Drapieżne tylko kraczą. Nocne tylko huczą. Pstropióre i błotne tylko wrzeszczą, jak czajka, sroka, dudek, paw itd.. Milczą tylko ryby i gady. A czemu to tak? Otóż

${ }^{81}$ Ibid., 407.

82 Ibid., 413. Among the creatures indicated by Odyniec only snails and only from the sea family (ormets, whelks) are considered seafood. One could also identify crustaceans (lobsters, Dublin bay prawns, crabs, and shrimp) and molluscs, including clams (e.g. oysters, mussels, scallops, and cockles), and cephalopods (cuttlefish, calamari, and octopi) with a separate subgroup of echinoderms, e.g. sea urchins.

${ }^{83}$ Odyniec only indicated that Venetian theriac was made of reptiles (413). In her recent guidebook Wenecja. Miasto, któremu się powodzi, (Warsaw: Wielka Litera, 2020), 272-275, Manuela Gretkowska offered some more information. For that people boils vipers with various ingredients. We know that one of those ingredients was opium. Yet the composition of the concoction remains unclear; it was supposed to treat headaches and other ailments; it was sold in pharmacies.

${ }^{84}$ More on public gardens built by Napoleon's order - see Łucja Rautenstrauchowa, Miasta, góry i doliny (Poznań: Nowa Księgarnia, 1844), vol. 3, 106-108. 
właśnie w tym zapytaniu leży temat do dalszych medytacji i do analogii z poetami i z ludźmi. ${ }^{85}$

[we also went to Piazzetta and having sat on the staircase we chatted for an hour. The waves under a light breeze smacked with a gentle hum at our feet. Adam talked about the voices of nature arguing that they carry the original tuning fork and the principle of general harmony, measure and rhythm - both in music and in poetry. (The monotonous swash of waves against other waves, and at regular intervals, seemed the role model for French Alexandrines). If we could listen closely to the birds' song, we could find the same principle there as well. Poetry begins in the song of birds flying to the ground - the voices of tetrapods are prose. Only forest and field birds sing - small, grey and innocent. Only large and black ones, like black grouses, woodgrouses, turkeys, etc., mumble. Birds of prey only caw. Nocturnal birds only hoot. Those with colourful feathers and those that move in mud, like peewits, magpies, hoopoes, peacocks, etc., scream. Only fish and reptiles keep quiet. But why is that? Well, that question holds the topic of further meditation and analogies with poets and with people.]

They did not discuss, as one might expect, what naturally could be associated with discovering Venice. It is clear that the auditory experience, the hum of the waves crashing at their feet, had inspired the story which eventually transcended the here and now. It is difficult to state whether the conversation about nature's voices and their harmony was supposed to be a kind of a counterbalance for the experienced disharmony of the city or rather a kind of desire to hear nature speak in the rock-like Venice. Regardless of that, the example clearly indicates how much more Odyniec and Mickiewicz appreciated the voice of nature than the space saturated with art - the "monotonous swash of waves" seemed to remind them of the harmony of the world of sounds.

\section{Forefathers' Eve in Lido}

It was Goethe who indicated that in Lido there was a cemetery for Jews and the English. ${ }^{86}$ Possibly that was also the reason why Byron wished to be buried there. ${ }^{87}$ If one should trust Chateaubriand, the place was known to his contemporaries as it was marked by the poet. ${ }^{88}$ When setting off with Mickiewicz for Lido, Odyniec knew about Byron's wish. It is most probably for that reason that he saturated his depiction of the place with ideas outside conventional guidebook information. He wrote: "[Mickiewicz's] conversation in such a place, at such a time of day, and in such a mood and tone almost made such an impression on me as if I had seen Byron's ghost who while paying penance

\footnotetext{
${ }^{85}$ Odyniec, Listy z podróży, vol. 1, 447.

${ }^{86}$ Goethe, Podróż włoska, 80.

${ }^{87}$ See note 5 .

88 "Here is the border pole at the base of which Byron marked the place for his grave,"
} (François Renè de Chateaubriand, "Rozmyślania na Lido," in "Księga Wenecji," trans. Paweł Hertz, Zeszyty Literackie, issue 39 (1992): 87. 
there (...) was whispering all that into his ear seeking his substitute in him."19 In Lido, the author of Listy z podróży assigned Mickiewicz the role of guślarz [the 'wizard' or 'shaman' in Forefathers' Eve], who asked: "Can you feel who is here with us?"90 And he responded himself while Odyniec ${ }^{91}$ tried to reconstruct the poet's musings on Byron and Napoleon:

They both had grand missions in the society poisoned by the 18th century. They both hated evil which they saw around them, and they sensed the goodness towards which they were supposed to lead. They both had the power to do that, each to his own extent - and they both fulfilled their missions because they felt that power, in comparison only to people, it bore conceit in both, and conceit killed love - the only power capable of vanquishing evil. Byron, sensitive and passionate, extended his disdain for evil over all people failing to notice that they also carried virtues. Because of his disdain he concluded that they were not able to improve and even mocking their strive to do so he began insulting the society's moral opinion thinking that he was mocking their hypocrisy. His trip to Missolonghi occurred too late.

Napoleon, rational and cold, did not trust the rationality of others enough to invite them to jointly fulfil his plans. He sought in them mere tools and he wanted to do everything in everyone's stead and, as he probably thought, for everyone. In Elba, he realised that too late; and also, only on his death bed did his spirit match his genius, the inspiration of which he was not able to fulfil. Byron only irritated everything. Napoleon trampled only those evil things which they both felt in humanity and both wished to correct. ${ }^{92}$

\footnotetext{
${ }^{89}$ Odyniec, Listy z podróży, vol. 1, 419.

${ }^{90}$ Ibid., 418.
}

${ }^{91}$ Of course, there is no clear proof that Mickiewicz's reflections were recorded accurately by Odyniec. In fact, the author of the account made the reservation that he could not fully recreate that which had been said by the poet. The account's schematic nature raises doubt whether Odyniec did not taint Mickiewicz's statement with his own critical view of Byron. One could assume that the author of Listy z podróży referred to an essay by William Hazlit of 1824 who keenly attacked the author of Childe Harold's Pilgrimage for his individualism and exoticism (William Hazlit, Eseje wybrane, trans. Henryk Krzeczkowski (Warsaw: PIW, 1957)). Most certainly Odyniec was also familiar with the later critical evaluations of Byron's works, e.g. those by Edward Dembowski ("Piśmienność powszechna," Przegląd Naukowy, issue 10, (1843): 31-32) or Antoni Czajkowski "Pola elizejskie" printed in Poezje, (Warsaw: Drukarnia Stanisława Strąbskiego, 1845). It was in his argument that conceit was the dominant feature of Byron's character.

In Listy z podróży, Odyniec was critical of the English poet at least twice: one time in the rhymed address opening the story of his visit in Venice: "A przecież - gdyś ty szczerze tak się ludźmi brzydził,/ Żeś ich wciąż jak psów łajał, jak psów nienawidził,/ To skąd ci ta ochota pisać dla nich wiersze?" [Alas, since you were so disgusted by people,/ That you scolded them like dogs, hated them like dogs,/ Then why did you feel the urge to write poems for them?] (402). He also quoted the critical remarks about Byron by a Swiss writer by the name of Charles Victor de Bonstetten, whom he met in Rome (vol. 2, 86-87). It is possible that Mickiewicz was inspired by his arguments when he wrote the foreword to The Giaour comparing Voltaire's and Byron's protagonists - see Adam Mickiewicz, "Przemowa tłumacza," in G.G. Byron, Giaur. Ułamki powieści tureckiej, trans. Adam Mickiewicz, ed. Stefan Treugutt (Warsaw: PIW, 1986), 32.

${ }^{92}$ Odyniec, Listy z podróży, vol. 1, 419. 
Mickiewicz appreciated their grandeur, yet he was, according to Odyniec, critical; he reprimanded them on their conceit. He was similarly prophetic in stating that the work started by Byron and Napoleon shall be continued by "new exiles" who in "the new spirit of love and humility shall move their work forward." 93 Thus, the poet indicated a need for change. In 1829, his works did not herald it yet. In Forefathers' Eve Part IV and in Konrad Wallenrod, he closely followed Byron's rebellious spirit. ${ }^{94}$ It was only in Part III of Forefathers' Eve written in Dresden that he overcame Romantic individualism. ${ }^{95}$ It is possible that the process had already began in Venice. The fact of coming into contact with the traces of "the giants of the epoch" and the very fact of experiencing the city might have inspired him to spin Romantic reflections on the past, the present and the future. The contrast between the Doge's Palace, the symbol of Venice's former glory, and the ruin of especially the palaces along the Grand Canal and Austrian captivity had to lead to melancholic ascertainments. Everything reminded him of the instances of grandness which collapsed - Venice, dear Byron, ${ }^{96}$ dear Napoleon, and (as

\section{Ibid.}

94 Though one could find a crack in the creation of Alpha Konrad. It emerged at the moment of making his tragic choice and bidding Aldona farewell by saying "you are the widow of a grand man." And it culminated in an echo of the statement, a painful confession doubting his former conviction about the justness of the decision: "Grandness! grandness once again, my angel!/ Grandness for which we groan in misery./ A few more days, may the heart live through the pain,/ It's done, there's no sense in regretting the past," (Adam Mickiewicz, Konrad Wallenrod, ed. Stefan Chwin (Wrocław-Warsaw-Krakow: Ossolineum, 1991)), 40, lines 162-165.

${ }_{95}$ The process was indicated in his Roman and Dresden lyrical works, and it was accentuated by Zdania i uwagi.

${ }^{96}$ Mickiewicz's known statements both before his visit in Venice and from his later ones do not confirm the acuteness of the judgement on Byron as indicated by Odyniec in Listy z podróży. The poet never accused Byron of being conceited. On the contrary, he defended rather than attacked him. Neither did he state anything about his downfall. It seems that Odyniec mostly forced his own interpretation. That is why it difficult to reliably recreate Mickiewicz's opinion of Byron from 1829 - even more so considering the fact that it changed as the English poet's works evolved, and because of Mickiewicz's dynamic attitude, and, possibly, because of the Zeitgeist. Mickiewicz's first significant statement on the matter came from his letter to Malewski: "I only read Byron, I toss a book written in a different spirit aside as I dislike lies," (Adam Mickiewicz, "List do Franciszka Malewskiego z 20 listopada 1822 r.," in Adam Mickiewicz, Dzieła (Warsaw: Czytelnik, 1955), vol. XIV, 192). That "candour" and expression can also be found in Part IV of Forefathers' Eve and in Konrad Wallenrod. The other statement was associated with his unfinished study entitled Goethe i Byron (in Polish). In it, he confirmed his fascination with Byron, whom he considered equal to Goethe - "a giant." Finally, in Mickiewicz's Introduction to the Polish edition of The Giaour of 1834, one can find a fragment parallel to his statement from Lido. Most probably because Odyniec paraphrased a fragment of Byron's The Corsair, to which Mickiewicz also referred: "The young author [Byron], persecuted by critics, pursued them in return, and by judging readers based on critics he help the entire audience in contempt. After that author's quarrel with writers, a moral rupture with people occurred, the details of which belong to his biography. "Filled with anger, cursing hypocrisy,/ Though he knew, he forgot there were people who were better" (The Corsair) "Wstęp do Giaura," in Byron, Giaur, 31), It is unclear whether in reconstructing Mickiewicz's statement Odyniec used the introduction to Giaur or whether already then, in 1829, the poet had that opinion of Byron. Yet that Introduction seems important for another reason. The poet wrote in it: "The common opinion referred to Byron as a Napoleon of poets, and Napoleon was considered France's only poet." Mickiewicz, as noted by Stefan Treugutt, uncovered "the relationship between poetry and practical actions, the works of the poet and of the leader," ("Byron i Napoleon w polskim 
if by accident) led to associating the city's biography with the biographies of the "giants," as at the core of their experiences there - in Mickiewicz's approach as reported by Odyniec - lied power and conceit. In any event, in the account by the author of Listy z podróży, Venice was associated not with art, which became its superb trademark, but with the geniuses of the epoch, i.e. Byron and Napoleon.

micie romantycznym," trans. Maria Bożenna Fedewicz, in Geniusz wydziedziczony. Studia romantyczne i napoleońskie (Warsaw: IBL PAN, 1993), 116. One could, of course, wonder whether in 1829 Mickiewicz was able to make such a comparison. Clearly it was popular, even more so considering the fact that Byron himself was fascinated with Napoleon and jokingly compared himself to the French leader; moreover, he indicated that comparison in Don Juan. Odyniec's account also includes a comparison of poetry and actions. Mickiewicz referred to that not only in the introduction to the Polish edition of The Giaour, but also in his Paris lectures. It seems that Venetian space could have inspired him to produce such reflections as it reminded him of both the English poet and the French leader, the latter of whom decided about the city's fate in 1797, and also later when he "sold" it to Austrians. Sadly, though, he largely caused its destruction, though he did author a few projects. It was his decision to build, e.g. public gardens and the second water barrier. When strolling through Venice, Mickiewicz came into contact with tangible traces of the fickle nature of fate: the former grandeur and the present Austrian captivity. In that context he surely wondered about his own future. The journey surely inspired him to think enabling him to confront his visions with reality. One could assume that Mickiewicz in Venice was not yet ready to take over Byron's role of a poet crossing the border between words and actions, and between works and life. That somewhat justifies the referenced opinion that Byron's "journey to Musolonghi came too late." It was as late as during his Paris lectures that Mickiewicz recognised the significance of the decision by the author of Manfred: "Lord Byron began an epoch of new poetry; he was the first who helped people feel the whole gravity of poetry; people saw that one should live as one wrote, and that a desire or words are not enough; people saw the rich poet raised in an aristocratic country abandon the parliament and his homeland to serve the Greek cause. That deeply felt need to poeticise one's life, and thus to bring an ideal closer to reality was Byron's entire poetic achievement. In fact, all Slavic poets have followed that path (...) Lord Byron, on his part, was a product of Napoleon. It is quite obvious for me that the flame that fuelled the fire of the English poet came from Napoleon's spirit. (...) Napoleon inspired Byron," (Adam Mickiewicz, “Wykład III z 20 grudnia 1842, Kurs trzeci 1842-1843," in Literatura Stowiańska. Kurs trzeci i czwarty, trans. Leon Płoszewski (Warsaw: Czytelnik, 1955), vol. XI, 32-35). It is worth noting that Mickiewicz in his Paris lectures (lecture on 20 December 1842, XI, 32-34) strengthened the relationship between poetry and practical actions - between art and politics. Napoleon became Byron's spiritual guide, and history was assigned the power of shaping poetry. Also in his lectures Mickiewicz indicated that "in the case of Byron and Napoleon their common feature was their moral power, which changes people and is able to shape life itself," (Treugutt, "Byron i Napoleon w polskim micie romantycznym," in Geniusz wydziedziczony. Studia romantyczne i napoleońskie, 116. Clearly, Mickiewicz's attitude towards Byron and his works underwent various transformations since the 1820s. It seems that its evolution confirmed Odyniec's account only to some extent as it would be difficult to specify the exact time and nature of the changes. That was proven, e.g. in a fragment of Mickiewicz's letter to Bohdan Zalewski: "You said it well and righteously that we need clasp towards love and humility. If dead Byron was among us, he would have surely strengthened us with humility," (Adam Mickiewicz, "List do Bohdana Zaleskiego z 23 czerwca 1841," in Dzieła, vol. XV, 400). The first fragment of the letter is aligned with the thought expressed by Mickiewicz in Listy z podróży indicating the fact of choosing a new path - that of "love and humility." Yet what seems significant, while disregarding the time when the reflection was written, is that the quoted argument was a response to a review of Beniowski, in which Zaleski accused Słowacki of "anger and conceit." In this context one could easily imagine Zaleski's opinion on Don Juan. At that time, though, both for Mickiewicz and Zaleski, Byron was an author who vanquished extreme Romantic individualism and gave his life in defence of Greece's freedom. Nothing else mattered in their assessment at that time. Byron's image was shaped by his legend. More on Mickiewicz and Byron - see Grażyna Halkiewicz-Sojak, "Mickiewiczowski Byron," in Byron w twórczości Norwida (Toruń: Wydawnictwo Naukowe w Toruniu, 1994), 22-34. 
Odyniec forged the reconstruction of Mickiewicz's musings on the "titans" intended to offer a universal conclusion about the need to fight against evil somewhat following reflections on the destructions of grand civilisations. Landscape and mood were the essential elements of the creation: "We set off so late on purpose so that we could view the seat of funeral/poetic memorabilia in moonlight." ${ }^{\prime \prime 7}$ They sailed alone to Lido, they sat in an empty place, they listened to the quiet interrupted by the sounds of the bells of Venetians churches for the Angelus and by the hum of sea waves. That whole space they could observe saturated with silence brought Byron to their minds ("We were on a hill over a plain on which Lord Byron often capered"98). Yet the statement by Mickiewicz which Odyniec quoted reached deeper. His musings about Byron and Napoleon, ${ }^{99}$ though to some extent

\footnotetext{
${ }^{97}$ Odyniec, Listy z podróży, vol. 1, 418.

${ }^{98}$ Ibid.
}

${ }^{99}$ Mickiewicz was fascinated with Napoleon. He considered him an ingenious leader who was able to transform the world. He credited him with awakening national awareness in Slavs (lecture on 29 April 1842, 282). Most of all, his existence assured the poet that an ingenious individual with moral strength could shape a new historical reality. He was also critical - he accused Napoleon of diverting from his mission and his crowning as emperor was proof of his moral downfall: "Napoleon guessed the hidden expectations of his time: he upheld them, and he cleared the path for their fulfilment but he failed to fulfil them himself. He fell. He was too late to discover the secrets of spiritual temptations, an excellent commentary to which he expressed during his imprisonment in Saint Helena" (lecture on 28 May 1844, 505). That evaluation did not, however, belittle the historical significance which Mickiewicz assigned to Napoleon, including in the vision of the future he was designing. He called him a "man of the globe, the most complete of men" (lecture on 19 March 1844, 449), who started the rebuilding of Europe. Mickiewicz argued that Napoleon's unfinished mission should be continued to produce a historical turn. That was why the poet expected the emergence of a new genius who, through his energy (light and strength), would continue the unfinished project. In Mickiewicz's perception, Napoleon became a man akin to Christ. It was through the "pain of his experiences" in Saint Helena Island that he gained his new power: "Napoleon's earthbound existence ceased. As a leader of a political party, as the head of a dynasty, Napoleon has no existence anymore. Yet who would dare to negate the permanent existence and influence of his spirit? Religious people, warriors, and statesmen use his wisdom, carefully studying his writings and deeds. Is such a study not a true prayer? It is the duty of inspired artists to rise to the land where that grand spirit resides, bring him about and make it visible to us." The poet thus spoke during his Paris lecture on 30 January 1844, i.e. 15 years after the attempt to outline Napoleon's portrait in Lido. At that time, if one were to trust Odyniec, he indicated Napoleon's extreme individualism. Later, in his Paris lectures and in the Trybuna Ludów journal, Mickiewicz shaped Napoleon's biography using his early Republic period and the period associated with his internment in Saint Helena. That mode of depiction was also applied somewhat in the Lido remarks, in which the final years of Napoleon's life were considered as a kind of propitiation: "only on his death bed, the spirit in him stood equal to the genius the inspiration of which he did not manage to fulfil," (Listy z podróży, 419). One should add that in Mickiewicz's remarks as reconstructed by Odyniec the fact of references to Elba raises doubts. The poet indicated several times, though only later in his Paris lectures, not Elba, as in the account by Odyniec, but Saint Helena. Quite certainly also because that was where Emanuel Las Cases wrote Mémorial de Sainte Hélène, a work written as directed by Napoleon. It was on its basis that Mickiewicz shaped the new image of the genius of his age - of a prisoner of the Holy Alliance and a spokesman of captive nations. One thing remained unchanged: both in the indicated account from Lido, and in his later remarks in his Paris lectures and in the Trybuna Ludów, the poet argued that the unfinished project by Napoleon the genius awaited a successor. See Maria Janion, Maria Żmigrodzka, Romantyzm i historia (Warsaw, 1978), 212-250; Treugutt, "Napoleon - mit i utopia," in Geniusz wydziedziczony. Studia romantyczne i napoleońskie, 7-34. 
applicable to the place where they were uttered, were directed towards the future. In Odyniec's framing, Lido became a place of musings on the world. ${ }^{100}$ He ostentatiously forced a Romantic aura on the scene: two wanderers standing near a tree embracing each other staring at the night-time landscape with the moon resembled a painting by Caspar David Friedrich entitled Two Men Contemplating the Moon (1819). Mickiewicz's musings were surely triggered by his Romantic longing for a materialisation of his dreams for a change, and the sight of the sea in the spirit of the paintings by Friedrich (Moonrise over the Sea, 1822; Seashore in Moonlight, 1835) inspired the poet with a "sense of endlessness" as he wondered who would adopt the ideals of "the giants" and "whether people will one day finish them before the world ends, not only the One who himself is that ghost and gave the world a model of himself."101

\section{City of "mysteries and lovers' rendezvous"}

That was the name that Odyniec gave Venice referring to the most resilient cultural cliché which has been one of the components of its image, i.e. the city of love. Most probably it was strengthened by the goddesses portrayed by Venetian painters: Venera, Venus, and Aphrodite. Literature consolidated that myth at the turn of the 19th century particularly strongly. It was perpetuated by many authors. For example, Ann Radcliffe in The Mysteries of Udolpho offered two extreme visions of Venice: a city of a love inspired by music; and a city of debauchery, passion, and gambling. In Corinne, Madame de Staël gave the queen of the Adriatic a melancholic atmosphere full of dark premonitions of the characters and she combined it with the expressions of their experiences culminating in a thunder storm which became a reflection of the unbridled power of their emotions. Byron also wrote about love, particularly in his letters. He did not bury the image of licentious Venice with extreme moral freedom, which he openly utilised. Yet the image of a love-filled sensual city which he consolidated had, just like in the case of Radcliffe's works, extreme faces. One of those was associated with a time of his promiscuity and Venetian lovers who fascinated him with their "wildness" and "tiger's" temperament. He thus wrote to Thomas Moore (Venice, 19 September 1818):

I wish you good night, with a Venetian benediction (...) "May you be blessed, and the earth which you will make" - is it not pretty? You would think it still prettier if you had heard it, as I did two hours ago, from the lips of a Venetian girl, with large black eyes, a face like Faustina's, and the figure of a Juno - tall and energetic as a Pythoness, with eyes flashing, and her dark hair streaming in the moonlight - one of those women who may be

${ }^{100}$ Lido became the location for Romantic musings - see Chateaubriand, "Rozmyślania na Lido," in "Księga o Wenecji," selected and trans. Paweł Hertz, Zeszyty Literackie, issue 39 (1992): 86-88; Z. Krasiński, “List do ojca z 28 września 1833,” in Listy do różnych adresatów, collected, ed. and introduction Zbigniew Sudolski (Warsaw, 1991), vol. 1, 34.

${ }^{101}$ Odyniec, Listy z podróży, vol. 1, 419. 
made any thing. I am sure if I put a poniard into the hand of this one, she would plunge it where I told her - and into me, if I offended her. I like this kind of animal, and am sure that I should have preferred Medea to any woman that ever breathed. ${ }^{102}$

Byron's promiscuity, with his inclination for energetic and vivacious sensual lovers, had its end when at countess Benzoni's parlour he met Teresa Guicciolli, his final love. In his letters to her he succumbed to the sentimental/Romantic atmosphere of such confessions:

Dearest (...) For the past few years I have tried to systematically avoid any passion as the tyranny of love has brought too much pain on me. Never to indulge in adoration, never to revel (...) I was supposed to never love anyone again or expect being loved. You have shattered all my resolutions. Now I belong to you whole, what I will become it all depends on You - maybe a happy man in Your love, but forever restless. You should not have awoken my heart anew because (at least in my country) my love has always been despair for those whom I loved, and myself. Yet those reflections come too late. You were mine, and how ever it all unfolds, I am Yours and I shall remain like that forever. ${ }^{103}$

Clearly, then, Byron consolidated - particularly in his personal documents, letters and memoirs - the myth of Venice as a city of love reminding that no one kisses like a Venetian.

Under the pressure of a whole host of cultural patterns, Odyniec included a story in his account which he treated like an equivalent of a love story inseparably connected with Venice. It included a mysterious female protagonist known as signora Rachela and a male protagonist named Adam Mickiewicz. They met during their journey from Milan to Venice. It is unclear who she actually was but thanks to Odyniec her description is known:

młoda, kształtna, wysoka z pałającymi czarnymi oczyma, z czarnym mediolańskim welonikiem na głowie, a przy tym wcale przystojna i z twarzą pełną życia i wyrazu, zdaje się uosabiać w sobie typ mediolanek i włoszek. Dotąd, kto ona jest, z pewnością nie wiemy, ale ze wszystkiego się zdaje, że musi być aktorką, bo zna dobrze dramatyczną literaturę włoską i ogólną, i o teatrze z wielką znajomością rzeczy rozmawia, a przy tym ma widocznie wyższe wykształcenie, mówi płynnie po francusku, chociaż z włoskim akcentem, a tak $\mathrm{w}$ tonie, jak $\mathrm{w}$ wyrażeniach nieco na teatralną deklamacją i sentymentalność zakrawa. Imię nawet ma poetyczne: Rachela. ${ }^{104}$

102 Byron, “List do Tomasa Moore'a, Wenecja 19 września 1818," in Listy i pamiętniki, 200. [English version: https://www.lordbyron.org/monograph.php?doc=ThMoore.1830\& select=AD1818.21]

${ }^{103}$ Byron, “List do hrabiny Guiccioli, Wenecja 25 kwietnia 1819," in ibid., 210. [English version translated from Polish]

${ }^{104}$ Odyniec, Listy z podróży, vol. 1, 373. 
[young, shapely, tall with glowing black eyes, with a small black Milanese veil on her head, and yet quite handsome and with a face full of life and expression, she seems to embody the typical Milanese or Italian woman. We still don't know who she is but based on everything we do know it seems that she must be an actress as she knows Italian and general dramatic literature well, and she talks with great knowledge about theatre, and clearly has university education, she speaks fluent French though with an Italian accent, and both in terms of her tone and expression with a slight tint of theatrical recitation and sentimentality. Even her name - Rachela - is poetic.]

She remained the story's mysterious character:

Ale czy ona sama, jak wnoszę, a raczej się domyślam, jest istotnie kapłanką Melpomeny? - o tym z pewnością powiedzieć nie umiem, bo jak arabska gościnność, tak europejska grzeczność nie pozwalają pytać nikogo: „Ktoś jest?", tym bardziej kiedy już samo ,jak jest” aż nadto do przyjemności towarzystwa wystarcza i jak podróż, tak i pobyt nasz w Wenecji dla obu nas wielce umila. ${ }^{105}$

[But is she herself, as I infer or suspect rather, truly Melpomena's priestess? - that I surely cannot state because just as Arabian hospitality so does European politeness prevent me from asking anybody: "Who are you?" even more so when the very "how is it" suffices completely for the pleasure of the company, and makes both our journey and stay in Venice pleasant for us both.]

It is unclear what Mickiewicz thought about her, yet Odyniec's account indicates how the poet behaved. The poet was drawn to talk with the mysterious signora. He was polite - he offered his hand as she was disembarking a carriage, and he carried her travel basket. We also know that she inclined him favourably: "Adam would surely normally be anxious by now if it had not been for the calming influence of signora Rachela."106 In Venice, just like other Polish travellers, she moved from a hotel to a private house and resided near their quarters. Odyniec offered the following account: "Adam also exercised extremely in the company of signora Rachela,"107 and used the opportunity to complain: "politeness, which demands him to take care of her, draws Adam away from me."108 Rachela participated in the trips they organised. Together they celebrated vine harvest in Lido. They ventured to Malamocco and Murazi. From a gondola, they admired Venice. Finally, they visited theatres together. They bought seats a booth for her. From his account, readers know that Odyniec parted with Adam at dusk: "at that time he sets off into the world following his 
own path and we don't meet like we used to in an agreed café in front of the theatre or after returning home at night." ${ }^{109}$ During that time, as one might presume, Mickiewicz met with signora Rachela. Because of that, he spent much money, which was the reason of his quarrel with Odyniec. The author of Listy suggested that between the poet and the mysterious lady there formed some kind of a bond: "Clearly, parting for Adam is not easy as he still has not returned."110 In her attire, Rachela - "wrapped in black mantilla and covered with a black veil"111 - also manifested the melodramatic atmosphere of their parting. According to Odyniec's recollection published by Kazimierz Wójcicki, one can also learn that Venice "impacted Adam more than Milan ever did."112 Yet he did not confirm that opinion in Listy z podróży. In the account of their visit in Venice, he discussed Mickiewicz's impressions extremely rarely.

Therefore, the Venetian thread in Mickiewicz's biography remains veiled in mystery. That is mainly because, except for Odyniec's testimony, there are no other sources to which one could refer. Mickiewicz did not write a single letter from Venice. When he wrote Franciszek Malewski already from Rome (30 November), he only confessed that "Between Milan and Venice I was constantly ill and suffered a toothache."113 Due to the lack of documents, most of the poet's biographers did not discuss that topic. ${ }^{114}$ Piotr Chmielewski, who started already in the 19th century an extensive biographical narrative about the poet, wrote:

Mickiewicz większą część wieczorów spędził ze swoją nową znajomą, panną Rachelą; a drobne jego wydatki „zaczęły tracić coraz bardziej swój jednostkowy charakter tak, że Odyniec, który był kasjerem Adama, ośmielił się w końcu zwrócić na to jego uwagę. Adam zrzucił go kilku suchemi słowami z urzędu kasjera i pieniądze swoje wziął do siebie."115

[Mickiewicz spent spent most of his evenings with his new acquaintance, Ms Rachela; and his petty expenses "started losing their infrequent nature so much so that Odyniec, who was Adam's cashier, eventually dared to indicate that to him. In a few bitter words, Adam relieved him of his duties as cashier and took the money himself."]

${ }^{109}$ Ibid., 415.

${ }^{110}$ Ibid., 447.

${ }^{111}$ Ibid., 451.

112 Kazimierz Władysław Wójcicki, Wspomnienie o życiu Adama Mickiewicza (Warsaw: Mierzbach, 1858), XLVIII.

${ }^{113}$ Adam Mickiewicz, "List do Franciszka Malewskiego, [Rzym] 30 listopada [1829]," in Listy. Część I, ed. Stanisław Pigoń (Warsaw: Czytelnik, 1955), vol. XIV, 506.

${ }^{114}$ It is symptomatic that Kronika życia i twórczości Adama Mickiewicza about the year 1829 has never been developed.

115 Piotr Chmielowski, Adam Mickiewicz. Zarys Biograficzno-literacki, 2nd edition, amended with two portraits of the poet (Warsaw: Gebethner i Wolff, 1898), vol. II, 45. Odyniec stated: "I lugged that gold in my pocket and having paid for our joint travel expenses I gave its owner only enough for petty expenses. But those expenses in Venice began to lose their petty character, so as a loyal guard of the treasure I finally dared to make a remark about that" (Listy z podróży, vol. 1, 509). 
Józef Kallenbach did not discuss Mickiewicz's visit in Venice, ${ }^{116}$ nor did Juliusz Kleiner, ${ }_{117}^{117}$ Mieczysław Jastrun,118 Jacek Łukasiewicz, ${ }^{119}$ Tomasz Łubieński ${ }^{120}$ or Bohdan Urbankowski. ${ }^{121}$ Roman Koropeckyj proved bolder than Polish literary historians and in a daring biography - as denoted by its publishers - entitled Adam Mickiewicz. Życie romantyka. he thus described the issue:

\begin{abstract}
Do Wenecji Odyniec i Mickiewicz przyjechali 7 października z listami polecającymi od pani Szymanowskiej i od księżnej Wołkońskiej do jednego z miejscowych muzyków. Zostali w mieście dwa tygodnie, obejrzeli wszystkie atrakcje polecane przez Guide de voyageur Odyńca i jednocześnie starali się zobaczyć Wenecję Childe Harolda. Być może dzięki temu Wenecja wydała się Mickiewiczowi o wiele bardziej czarodziejska, niż była naprawdę - a może to dzięki znajomości z niejaką Rachelą (,[[musiała] być aktorką"), z którą dzielił karetę (i najprawdopodobniej także łóżko) w drodze do Wenecji, a następnie również zwiedzał miasto. Nic więc dziwnego, że Wenecja, perła Adriatyku, „więcej niż Mediolan działała na Adama." 122
\end{abstract}

[Odyniec and Mickiewicz arrived in Venice on 7 October with letters of reference from Mrs Szymanowska and from duchess Wołkońska addressed to a local musician. They stayed for two weeks. They visited all the attractions recommended by Odyniec's Guide de voyageur and they also tried to see the Venice from Childe Harold's Pilgrimage. It is possible that because of that Venice seemed to Mickiewicz much more magical than it actually was - or maybe that was because of his acquaintance with one Rachela ("she must have been an actress"), with whom he shared the carriage (and most probably also his bed) while travelling to Venice, and later he also explored the city with her. No wonder, then, that Venice, the jewel of the Adriatic, "impacted Adam more than Milan ever did."]

One could wonder to what extent Odyniec used that considerably fragmented story basically consisting of shreds of information and unconfirmed conjectures to boost the appeal of his travel narrative. It seems that the fact of locking the author in cultural stereotypes somewhat demanded the story to be a mystery if not a love story - all the more so considering his difficult position. He was not only the author and narrator of Listy z podróży,

${ }^{116}$ Józef Kallenbach, Adam Mickiewicz, 4th edition, extended embellished with 19 ilustrations (Lviv-Warsaw-Krakow: Ossolineum, 1926).

${ }^{117}$ Juliusz Kleiner, Mickiewicz, vol. 1, vol. 2, part 1 and 2. (Lublin: Towarzystwo Naukowe KUL, 1948).

${ }^{118}$ Mieczysław Jastrun, Mickiewicz, 3rd edition, vol. 1, 2 (Krakow: PIW, 1950).

${ }^{119}$ Jacek Łukasiewicz, Mickiewicz (Wrocław: Wydawnictwo Dolnośląskie, 1996).

${ }^{120}$ Tomasz Łubieński, M jak Mickiewicz (Warsaw: Świat Książki, 1998).

${ }^{121}$ Bohdan Urbankowski, Adam Mickiewicz. Tajemnice wiary, miłości i śmierci (Poznań: Zysk i S-ka, 1999).

122 R. Koropeckyj, Adam Mickiewicz. Życie romantyka, trans. M. Glasenapp (Warsaw: Grupa Wydawnicza Foksal, 2013), 167. Odyniec did not mention that they used a letter of reference written by Zeneida Wołkońska. The musician's name was Perucchini. 
but also its character. However, a fact which seems obvious, Odyniec's account mainly drew readers' attention not because it described his story, but because it described the fortunes of Mickiewicz.

\section{Siren}

The assignment of new names to Venice in various accounts (from travel narratives to tragedies) was usually an expression of the need to mark one's personal point of view. ${ }^{123}$ Though some unexpected events occurred there. In a letter to John Murray, Byron referenced Lady Morgan, the author of Italy, 124 who called Venice an "oceanic Rome." He himself used that term in The Two Foscari, a tragedy he wrote many months prior to reading her book. ${ }^{125}$

How did Odyniec invent such extreme "names" for the city on the lagoon? It seems that he used them for various purposes. He used the leviathan in a rhymed passage which was the culmination of the narrative on the Republic's imperial past. He gave it an allegorical meaning. He assigned a completely different, though not quite clear, function to the siren. Ann Radcliffe's The Mysteries of Udolpho might have been an indirect inspiration. It was Radcliffe who introduced the sea nymph into Venetian space and who described the landscape concealed underneath the water's surface. And most of all, she introduced a new point of view. Not the one from above, from a tower, which was so popular in travel accounts, but from below, from the seabed. One could argue that she expanded the city's scope by peering into the void, which in ballads is inhabited by water nymphs and mermaids, which also appeared in Childe Harold's Pilgrimage. By using that ballad trail, Odyniec referred directly to "Świtezianka" and, less overtly, to "Świteź," by introducing (not for the first time) some familiar Polish motifs into Italian space. It seems that Mickiewicz's fantastic world and language helped Odyniec express his vivid experiences of the place: Piazzetta with its openness to the coastline and the skyscape. Odyniec recorded such experiences in his writings extremely rarely. In this case, he tried to frame them using the words by the author of ballads:

I tak cię łechce, i tak cię znęca,

Tak ci się serce rozpływa,

Jak gdy tajemnie rękę młodzieńca

Ściśnie kochanka wstydliwa. ${ }^{126}$
Each stroke so enticing, each wave tempting so,

Heart pounding with warmth and delight,

The feeling a stolen touch would bestow

Of lover's coy hand in the night.

${ }^{123}$ Odyniec also used well-known naming clichés: “Oh, this Venice! It is a sphinx, it is an amphibian of cities, it is a rock mirage of the sea, it is a fantastic mask or a masquerade of the earth, it is worse than a Cretan labyrinth" (Listy z podróży, 403).

${ }^{124}$ Lady Morgan, L'Italy (Paris: Pierre Dufart, 1821). Lady Morgan was actually a nom de plume. She changed her maiden surname after getting married: from Sydney Owenson to her husband's surname Morgan and she started writing as Lady Morgan.

${ }^{125}$ Byron, "List do Johna Murraya z 23 sierpnia 1821 r.," in Listy i pamiętniki, 298-299.

126 A. Mickiewicz, "Świtezianka," in idem, Wiersze, edited by W. Borowy, E. Sawrymowicz, vol. 1 (Warsaw, 1955), 118. [English version: http://www.wordactive.pl/switezianka. html] Odyniec introduced minor changes to the stanza. 
In his account, that "seductress" was not Świtezianka or Lake Świteź, but the Venetian cityscape. To capture its charm, Odyniec used an extremely familiar paraphrase of a fragment of "Świteź,"127 replacing poetry with prose:

Bo wyobraźcie tylko sobie - niebo przeczyste, gwiaździste, lazurowe, z księżycem rozpromienionym w pełni, a oświecającym pod sobą drugie takież niebo na ziemi, tylko, że jakby żywe, ruchome, dyszące, a dyszące taką świeżością, a brzmiące wzdłuż wybrzeża takim szumem czy szmerem, że nie bierzcie za przesadę, gdy powiem, że jest to oddech albo śpiew syreny, który gwałtem w głąb ku niej pociąga. ${ }^{128}$

[And so, just imagine - clear star-studded blue sky, with the moon in full shine, shining onto another such heaven on earth, but as if alive, moving, panting, and panting with such freshness, and sounding along the shore with such hum or murmur that you should not consider it exaggerated when I say that it is a breath or the song of a siren that violently draws deep towards her.]

That passage was supposed to substantiate the enchantment and elevation which he called an ecstasy. That is actually one of the few fragments in his narrative which proved his admiration. He confessed: "at night the charm of a siren is even stronger. Yesterday I experienced that myself." Understandably he had to transform the Lady of Switeź, associated with a specific topography, into such a being which could be introduced into any space. Yet he did not chose the sea nymph from Radcliffe's novel but a siren. But one should not associate it with Greek traditions. In legends, sirens used sweet songs to lure travellers to devour them. They symbolised the temptations lurking for travellers to interfere in their spiritual evolution by bewitching them, keeping them on magical islands, or leading

${ }^{127}$ The lines of "Świteź" which might have inspired Odyniec to present his impressions from the Piazzetta:

Jeżeli nocną przybliżysz się dobą I zwrócisz ku wodom lice,

Gwiazdy nad tobą i gwiazdy pod tobą, I dwa obaczysz księżyce

Niepewny, czyli szklanna spod twej stopy Pod niebo idzie równina,

Czyli też niebo swoje szklanne stropy Aż do nóg twoich ugina:

Gdy oko brzegów przeciwnych nie sięga, Dna nie odróżnia od szczytu,

Zdajesz się wisieć w środku niebokręga, W jakiejś otchłani błękitu.
If at night you near midnight

And face the water,

Stars above and stars below, You will see two moons

Uncertain, a glass one under your feet A plain stretches to the sky,

So the sky also bends its glass ceiling All the way to your feet:

Until the eye reaches opposite shores, Cannot tell the bed from the top,

You seem to be hanging in the middle of the sky, In some blue void.

Adam Mickiewicz, "Świteź," in Dzieła. Wiersze, vol. 1, 108. [English version translated from Polish]

${ }^{128}$ Odyniec, Listy z podróży, vol. 1, 404. 
them to untimely death. ${ }^{129}$ For Odyniec, Venice the siren did not possess that power.

Was there, then, some other reason for introducing her into the world of Serenissima? One could indicate a well-known issue. In "Petersburg" Mickiewicz wrote: "Wenecka stolica,/ Co wpół na ziemi, a do pasa w wodzie/ Pływa jak piękna syrena-dziewica,/ Uderza cara"130 [Venetian capital,/ Half on land, half in water/ She swims like a beautiful virgin siren,/ Strikes the tzar]. The poet placed it in strong opposition to Petersburg: "A Wenecją stawili bogowie;/Ale kto widział Petersburg, ten powie:/ Że budowały go chyba Szatany"131 [And Venice was built by gods;/ But whoever saw Petersburg would say:/ That Devils must have built it]. The author used the comparison a few years later but it possible that he gave Venice the form of a siren in Odyniec's Listy z podróży. One might also find it puzzling that in juxtaposing it with Petersburg, he added esteem to the queen of the Adriatic assigning to it the qualities of divinity and virginity. He applied a similar type of comparison in "Pomnik Piotra Wielkiego," in which he elevated Marcus Aurelius above Peter the Great. Does that, however, mean that Mickiewicz, the author of "Morlach w Wenecji," did not share Odyniec's critical opinion of the city's imperial policy? Or maybe the image of Venice the siren/virgin was determined simply by the poetic strategy which he applied in "Petersburg" and "Ustęp"?

One could also inquire whether the fact of referring to Serenissima as a siren was somehow related to Poland as Odyniec himself mentioned Warsaw's symbol in Listy z podróży. The bond with his homeland was created through the direct reference to "Świtezianka" and the fairly obscure reference to "Świteź," in the latter of which Mickiewicz depicted a vision of a sunken city and introduced the topic of freedom, enslavement and "death which saves from shame." In addition, the "podpas rybi" [fish underbelly] invoked by Odyniec associated with Stanisław Trembecki's celebratory ode "Na dzień rocznicy elekcji Nayiaśnieyszego Stanisława Augusta Trzeciego, króla polskiego, to jest siódmy września" (1802), in which the author mused on the reasons for Poland's demise, creates a faint barely perceptible sense of association between the Venetian siren and Poland (Warsaw) ${ }^{132}$ It is worth noting that the motif was popular in national poetry of the $1840 \mathrm{~s}^{133}$ and

${ }^{129}$ See Juan Eduardo Cirlot, Stownik symboli, 398.

${ }^{130}$ Adam Mickiewicz, "Petersburg," in Utwory dramatyczne, vol. 3 (Warsaw: Czytelnik, 1955), 277, lines 36-40.

${ }^{131}$ Ibid., 277, lines 47-49.

${ }^{132}$ One could find in Childe Harold's Pilgrimage (Canto IV, 572, line 116-117) a motif which connects his Canto IV with "Świteź." Byron stated "Even in Destruction's depth, her foreign foes,/ From whom submission wrings an infamous repose." The poet wrote that about Venice. The female protagonists in Mickiewicz's "Świteź" faced a similar problem.

${ }^{133}$ Paweł Hertz, the author the anthology Zbiór poetów polskich XIX wieku, indicated in the notes to the book that the motif of Venice often appeared in post-November Uprising poetry as a cypher for Warsaw or conquered Poland in general. The cypher was used to avoid censorship. Such poems included "Noc w Wenecji” by Edmund Chojecki, and "Odpowiedź Wenecjanina. Na wiersz Edmunda Chojeckiego," a polemic with the former by Karol Baliński (Zbiór poetów polskich XIX wieku, arranged and ed. Paweł Hertz, book 2 (Warsaw: PIW, 1961), 89, 816-818; Edward Dembowski, "Śmierć żeglarza pod Wenecją"; Mieczysław Pawlikowski, 
Odyniec was particularly susceptible to cultural clichés. It seems, however, that he could not have referred to them directly as he maintained that he wrote Listy during their travels, i.e. in 1829, nor did he align the tropes that he used with any clearly defined principle. It is possible that he abandoned his original intention to build a parallel between Warsaw and Serenissima as his vision of an imperial, cruel, mercantile and pagan Venice would have eventually prevented him from drawing a link between the city on the lagoon and Poland (Warsaw). ${ }^{134}$ It remains unclear to what extent that was a result of Odyniec's xenophobia (or even his Catholicism) and to what that view was influenced by Mickiewicz, a defender of southern Slavs, who viewed Venice through the prism of his very recent Russian experiences. In this context, it is difficult to unequivocally indicate the reason why the author of Listy z podróży chose the form of a siren for "the queen of the Adriatic." The wavering unstable nature of Odyniec's judgements ${ }^{135}$ and Mickiewicz's experiences, which were rarely expressed overtly, prevent one from offering a satisfactory answer.

$* * *$

It appears that one can only with some certainty separate in Odyniec's account that which might have been inspired by Mickiewicz from that which can be assigned to the author of Listy z podróży. Those mainly include guidebook-like details regarding the sites they visited, and digressions which departed from the topic of Venice, e.g. remarks related to Mickiewicz's past and his relationship with Maryla Wereszczakówna and Warzyniec Putkamer, as well as remarks with a clearly educational character, and attempts at offering a lecture on art. One could also indicate a few biographical "snippets." Thanks to Odyniec, readers could learn that Mickiewicz read newspapers at Caffè Florian, that he visited the musical evenings at Percchini's, and that he frequented Venetian theatres. Odyniec provided various details, e.g. a description of the poet's Crimean coat. ${ }^{136} \mathrm{He}$ also indicated his travel companion's politeness towards their hosts, and he recalled a prank he pulled on Adam of drawing a moustache on his face as the poet was asleep. That is one of the ways in which Mickiewicz is present in Listy z podróży.

In his narration, Odyniec usually utilised first person singular, though sometimes he switched to plural, e.g.: "we twitched as if at a cannon's

\footnotetext{
"Pamiętnik pieśniarza" (Zbiór poetów polskich XIX wieku, arranged and ed. Paweł Hertz, book 3 (Warsaw, 1962), 67-69, 471-473).

${ }^{134}$ Mikołaj Sokołowski suggested that Odyniec saw glimpses of the fate of Poland in the fall of Venice. I do not see any basis for posing such a thesis though similar comparisons were common in Polish poetry, particularly in the 1840s. See M. Sokołowski, Wenecja, Atlas Polskiego Romantyzmu, NPLP IBL; http://nplp.pl/artykul/wenecja/ (accessed on 21.07.2020).

${ }^{135}$ When writing about Venice the siren, he depicted the Doge's Palace as a "cemetery statue of the former grandeur and glory of the Republic of Venice." Yet when he reflected on its mercantile nature, he had some doubts - he compared Venice's downfall to the "bankruptcy of a wealthy and eternal firm." Odyniec, Listy z podróży, vol. 1, 405-406.

136 "It had a Spanish cut, it was reddish, with a violet velvet liner, it has strings and tassels at the neck," ibid., 421.
} 
boom, ${ }^{137}$ when they were startled by the roar of the wings of pigeons setting off at the sound of the clock. At another location, he wrote: "We were occupied and astonished particularly by Venice itself"138; "we had visited all the galleries and we had been to at least fifty churches."139 Therefore, he indicated the shared nature of their experiences. He further specified the relationship between Mickiewicz and him. He emphasised the former's remarks: "in his face I saw he was serious," "and you could tell he felt the urge to speak his mind," "he continued - what? And how?, I shall never forget it." ${ }^{\prime 140}$ It is worth noting that the travellers' first visit to Lido was filled with the poet's musings. Another such space of Mickiewicz's distinct presence in the story was the Doge's Palace. A visit in it was a pretext to reflect on the history of the Republic. Interestingly, Odyniec constructed the story about it in opposition to Byron's and Chateaubriand's views, two men of letters who were fascinated with Venice's history. Odyniec did not share their enthusiasm. For him, the city on lagoons was not, like it was Krasiński, "a golden urn of the past." It seems that his rejection of the views of renowned artists was amplified by Mickiewicz's critical attitude. It is fairly possible that the poet overlaid his Russian experiences onto the Venetian space seeing between them some historical analogies. That mode of thinking was confirmed in his "Morlach w Wenecji," a poem which was also an indictment of the imperial city state. Odyniec's conviction was also aligned with the poet's behaviour in the Doge's Palace, where the latter manifested his disgust for the barbarity of Venetian authorities. That was when the author of Listy wrote about their joint refusal to view torture devices: "We did not possess that curiosity, and when our guide wanted to force us to view them, Adam turned away in disgust." ${ }^{141}$ Saint Mark's Clocktower was another place where Odyniec manifested his experience-based bond with Mickiewicz. They both watched Venice from above. Odyniec referenced Zara (Zadar), the capital of Dalmatia. That, in turn, was a direct reference to "Morlach w Wenecji." It defined Mickiewicz's field of influence in the travel account. The influence may have reached deeper. Viewing the city from above, it was as if the travellers jointly became the authors of the allegorical image. One might even suspect that it was the poet who suggested to Odyniec to refer to the "queen of Adriatic waves" as Leviathan. It is widely known that that evil creature was included in the circle of visions of the author of Forefathers' Eve Part III and, though in a different meaning, also in Pan Tadeusz. ${ }^{142}$ It is possible that the situation was different. Possibly Mickiewicz did not encourage

\footnotetext{
${ }^{137}$ Ibid., 406.

${ }^{138}$ Ibid., 448-449.

${ }^{139}$ Ibid., 442.

${ }^{140}$ Ibid., 418.

${ }^{141}$ Ibid., 431.
}

142 "'Your name?' 'Lucrece, Leviathan,'” Adam Mickiewicz, Forefathers' Eve part III, scene III, 175, line 106; "The ancient Lithuanians knew as well, (...) That the zodiacal Dragon, winding thick (...) It's fish, not snake; Leviathan it's called," Adam Mickiewicz, Pan Tadeusz, ed. Stanisław Pigoń (Wrocław-Warsaw-Krakow: Ossolineum, 1967), book VIII, 380, lines 87-97. [English version: Adam Mickiewicz, Pan Tadeusz. The Last Foray in Lithuania, trans. Bill Johnston (New York: Archipelago Books, 2018)] 
Odyniec to thus shape his image of Venice, but it was rather Odyniec who read that from Mickiewicz's texts.

It seems that Odyniec felt the strongest bond with Mickiewicz on the stairs of Piazzetta as they listened to swashing waves and talked about the harmony of sounds. At that time, in that act of being together, the line between them got blurry. It was also from Piazzetta that Odyniec admired the nightscape. In that instance, the poet also played a role. In order to capture the special nature of the experience, the author of Listy used Mickiewicz's words to reflect the uniqueness of his impressions. He was a visitor from a rustic state and that which moved him the most profoundly was the sight of the island with moonlight in the background, the water surface reflecting the sky, and the sunset. One can presume that Mickiewicz observed Venetian nature with similar keenness. It moderated the dark image of the city where even Saint Mark's Basilica haunted Odyniec with its lion's appearance.

Therefore, it is clear that the depiction of Venice in Listy z podróży was influenced by Mickiewicz and it was he who directed readers' attention in a direction different from that indicated by, e.g. Chateaubriand, i.e. not towards admiration of beauty but mainly towards history and the future. That is also probably why their story includes no indication of the poet's admiration or aesthetic inclinations. It rather indicates his aversion to the imperial politics of the Republic of Venice, but also a dream about poetry which would change the world and about a genius (a new Napoleon) who would transform the reality. That was the fabric of which that image of Venice was made. Odyniec did try to complete the story by reflecting on love and beauty in art, but with no major success.

It seems that one cannot unequivocally define the borderline between Odyniec's and Mickiewicz's perceptions of Venice. That is mainly because the author of the account failed to indicate his point of view anywhere in it, as if there was no difference between him and the poet in their impressions evoked by the city. Quite the contrary, he allowed readers to consider their inferences as being identical. Thus, Odyniec's Venice simultaneously was and was not Mickiewicz's Venice.

\section{REFERENCES}

Achtelik, Aleksandra. Wenecja mityczna w literaturze polskiej XIX i XX wieku. Katowice: GNOME, 2002.

Ackroyd, Peter. Wenecja. Biografia. Translated by Tomasz Bieron. Poznań: Zysk i S-Ka, 2015.

Angielscy "Poeci jezior" William Wordsworth, Samuel Taylor Coleridge, Robert Southey. Selected, translated, introduction and commentary by Stanisław Kryński. Wrocław-Warsaw-Krakow: Ossolineum, 1963.

Brahmer, Mieczysław. Powinowactwa polsko-włoskie: Z dziejów wzajemnych stosunków kulturalnych. Warsaw: PWN, 1980. 
Byron, Lord. Listy i pamiętniki, edited by Juliusz Żuławski. Translated by Zygmunt Kubiak, Stanisław Kryński, Bronisław Zieliński et al. Warsaw: PIW, 1960.

Byron, Lord. "Wędrówki Czajdl Harolda." Translated by Jan Kasprowicz. In Wybór dziet, selected, foreword, edited and notes by Juliusz Żuławski. Vol. 1. Warsaw: PIW, 1986.

Chateaubriand, François Renè de. "Księga o Wenecji." Translated by Paweł Hertz. Zeszyty Literackie, issue 39 (1992): 79-88.

Chateaubriand, François Renè de. Pamiętniki zza grobu. Selected, translated and commentary by Joanna Guze. Warsaw: PIW, 1991.

Chmielowski, Piotr. Adam Mickiewicz. Zarys biograficzno-literacki. 2nd edition with two portraits of the poet. Vol. II. Warsaw: Gebethner and Wolff, 1898.

Cirlot, Juan Eduardo. Stownik symboli. Translated by Ireneusz Kania. Krakow: Znak, 2000.

Czaja, Dariusz. “Wenecja i śmierć: konteksty symboliczne." Konteksty, issue 3-4 (1992): 58-65.

Czaja, Dariusz. "Wenecja jest kobietą. Rzecz o wyobraźni." Konteksty, issue 3-4 (1995): 146-152.

Czaja, Dariusz. “W drodze do Wenecji. Podróże imaginacyjne." In Wędrować, pielgrzymować, być turystą. Podróż w dyskursach kultury, Studies directed by Piotr Kowalski, 137-154. Opole: Wydawnictwo Uniwersytetu Opolskiego, 2003.

Czajkowski, Michał. "Pola elizejskie." In Poezje. Warsaw: Drukarnia Stanisława Strąbskiego, 1845.

Daru, Pierre. Historie de la républiqe de Venise. Vol. I-VIII. Paris: Firmin Didot, 1819.

Dembowski, Edward. "Piśmienność powszechna." Przeglad Naukowy, issue 10 (1843).

Goethe, Johann Wolfgang. Epigramy weneckie. Venezianische Epigramme. Selected and translated by Piotr Wiktor Lorkowski. Krakow: Miniatura, 1999.

Goethe, Johann Wolfgang. Podróż włoska. Translated, notes and afterword by Henryk Krzeczkowski. Warsaw: PIW, 1980.

Gretkowska, Emanuela. Wenecja. Miasto, któremu się powodzi. Warsaw: Wielka Litera, 2020.

Halkiewicz-Sojak, Grażyna. "Mickiewiczowski Byron." In Byron w twórczości Norwida, 22-34. Toruń, 1994.

Hazlit, William. Eseje wybrane. Translated by Henryk Krzeczkowski. Warsaw: PIW, 1957.

Janion, Maria. Żmigrodzka Maria. Romantyzm i historia. Warsaw: PIW, 1978.

Jastrun, Mieczysław. Mickiewicz. 3rd edition, Vol. 1. Krakow: PIW, 1950.

Kallenbach, Józef. Adam Mickiewicz, 4th edition, extended with 19 illustrations. Lviv-Warsaw-Krakow: Ossolineum, 1926.

Kleiner, Juliusz. Mickiewicz. Vol. 1, vol. 2, part 1 and 2. Lublin: Towarzystwo Naukowe KUL, 1948.

Koropeckyj, Roman. Adam Mickiewicz. Życie romantyka. Translated by Małgorzata Glasenapp. Warsaw: Grupa Wydawnicza Foksal, 2013.

Krasiński, Zygmunt. Listy do różnych adresatów. Collected, edited and foreword by Zbigniew Sudolski. Vol. 1. Warsaw: PIW, 1991. 
Królikiewicz, Grażna. Terytorium ruin. Ruina jako obraz i temat romantyczny. Krakow: Universitas, 1993.

Kubacki, Wacław. Smutna Wenecja. Warsaw: Czytelnik, 1968.

Lady, Morgan. L'Italy. Paris: Pierre Dufart, 1821.

Łubieński, Tomasz. M jak Mickiewicz. Warsaw: Świat Książki, 1998.

Łukasiewicz, Jacek. Mickiewicz. Wrocław: Wydawnictwo Dolnośląskie, 1996.

Mickiewicz, Adam. Konrad Wallenrod, edited by Stefan Chwin. WrocławWarsaw-Krakow: Ossolineum, 1991.

Mickiewicz, Adam. Literatura słowiańska. Kurs pierwszy. Pótrocze I. Translated by Leon Płoszewski. Vol. VIII. Warsaw: Czytelnik, 1955.

Mickiewicz, Adam. "Morlach w Wenecji. Z serbskiego." In Dzieła. Wiersze, edited by Wacław Borowy, Eugeniusz Sawrymowicz, 311-312. Vol. 1. Warsaw: Czytelnik, 1955.

Mickiewicz, Adam. Pan Tadeusz, edited by Stanisław Pigoń. Wrocław-Warsaw-Krakow: Ossolineum, 1967.

Mickiewicz, Adam. "Petersburg." In Utwory dramatyczne. Vol. 3. Warsaw: Czytelnik, 1955.

Mickiewicz, Adam. "Przemowa tłumacza." In George Gordon Byron, Giaur. Ułamki powieści tureckiej. Translated by Adam Mickiewicz, edited by Stefan Treugutt. Warsaw: PIW, 1986.

Mickiewicz, Adam. "Świtezianka," “Świteź." In Wiersze, edited by Wacław Borowy, Eugeniusz Sawrymowicz, 114-120, 107-114. Vol. 1. Warsaw: Czytelnik, 1955.

Mickiewicz, Adam. “Wykład III z 20 grudnia 1842, Kurs trzeci 1842-1843.” In Literatura Słowiańska. Kurs trzeci i czwarty. Translated by Leon Płoszewski. Vol. XI. Warsaw: Czytelnik, 1955.

Miłosz, Czesław. “Legenda miasta-potwora." In Prywatne obowiązki, 189-197. Olsztyn: Pojezierze, 1990.

Odyniec, Antoni Edward. Listy z podróży, edited by Marian Toporowski. Introduction by Maria Dernałowicz. Vol. 1, 2. Warsaw: PIW, 1961.

Płaszczewska, Olga. Wizja Włoch w polskiej i francuskiej literaturze okresu romantyzmu (1800-1850). Krakow: Universitas, 2003.

Poklewska, Krystyna. "Mickiewicz i Mérimée. Z dziejów dwóch wierszy Mickiewicza." In Obrazki z romantyzmu. Szkice o ludziach, tekstach i podróżach, 11-18. Łódź: Wydawnictwo Uniwersytetu Łódzkiego, 2016.

Pomian, Krzysztof. Wenecja w kulturze europejskiej. Lublin: Wydawnictwo Uniwersytetu Marii Curie-Skłodowskiej, 2000.

Radcliffe, Ann. Tajemnice zamku Udopho. Romans strofami poezji przetykany. Translated by Wacław Niepokólczycki. Illustrations by Roman Cieślewicz. Warsaw: PIW, 1977.

Rautenstrauchowa, Łucja. Miasta, góry i doliny. Vol. 3. Poznań: Nowa Księgarnia, 1844.

Rybicka, Elżbieta. “Gesty demityzacyjne." In Modernizowanie miasta. Zarys problematyki urbanistycznej w nowoczesnej literaturze polskiej, 71-80. Krakow: Universitas, 2003.

Rybicka, Elżbieta. "Problematyka urbanistyczna w literaturze polskiej XVIII i XIX wieku (Wybrane zagadnienia)." In Modernizowanie miasta. 
Zarys problematyki urbanistycznej w nowoczesnej literaturze polskiej, 33-70. Krakow: Universitas, 2003.

Sciré, Nepi Giovanna. Gentili, Augusto. Romanelli, Giandomenico. Rylands, Philip. Wenecja. Arcydzieła malarstwa. Translated by Tamara Łozińska. Warsaw: Arkady, 2014.

Shelley, Percy Bysshe. Poezje wybrane. Selected, edited and introduction by Juliusz Żuławski. Warsaw: PIW 1961.

Sokołow, Nikołaj. Narodziny weneckiego imperium kolonialnego. Translated by Zdzisław Dobrzyniecki. Warsaw: PIW, 1985.

Sokołowski, Mikołaj. Wenecja, Atlas Polskiego Romantyzmu. NPLP IBL. http:// nplp.pl/artykul/wenecja/ (accessed on 11.08.2020).

Staël, Germaine de. Korynna czyli Włochy. Translated by Łucja Rautenstrauchowa, Karol Witte, edited by Anna Jakubiszyn-Tatarkiewiczowa. Wrocław-Warsaw-Krakow: Ossolineum, 1962.

Szyszkowski, Wacław. Wenecja. Dzieje republiki 1726-1797. Toruń: Towarzystwo Naukowe Torun, 1994.

Treugutt Stefan. "Byron i Napoleon w polskim micie romantycznym." Translated by Maria Bożenna Fedewicz. In Geniusz wydziedziczony. Studia romantyczne i napoleońskie, edited by Maria Prussak, 107-118. Warsaw: IBL PAN, 1993.

Treugutt, Stefan. “Napoleon - mit i utopia." In Geniusz wydziedziczony. Studia romantyczne i napoleońskie, edited by Maria Prussak, 7-34. Warsaw: IBL PAN, 1993.

Urbankowski, Bohdan. Adam Mickiewicz. Tajemnice wiary, miłości i śmierci. Poznań: Zysk i S-ka, 1999.

Wat, Aleksander. Korespondencja. Selected, edited, commentary and introduction by Alina Kowalczykowa. Vol. II. Warsaw: Czytelnik, 2005

Wójcicki, Kazimierz Władysław. Wspomnienie o życiu Adama Mickiewicza. Warsaw: Merzbach, 1858.

Zahorski, Andrzej. Spór o Napoleona we Francji i w Polsce. Warsaw: PWN, 1974.

Zahorski, Andrzej. Z dziejów legendy napoleońskiej w Polsce. Warsaw: PZWS, 1971.

Zbiór poetów polskich XIX wieku. Book 2. Arranged and edited by Paweł Hertz. Warsaw: PIW, 1961.

Zbiór poetów polskich XIX wieku. Book 3. Arranged and edited by Paweł Hertz. Warsaw: PIW, 1962.

Anna Kurska - Ph.D. hab., professor emeritus of Jan Kochanowski University of Kielce. She focusses on the issues of the Romantic essay, 19th-century travel writing, and Romantic inspirations in popular culture. She is the author of: Fragment romantyczny (1988), Kartoteka Tadeusza Różewicza (1991), Polska romantyków (1993), Zamek romantyczny w kilku odstonach (2010).

E-mail: annakurska@op.pl 